\title{
Carbonate phases rich in magnesium in the Triassic limestones of the eastern part of the Germanic Basin
}

\author{
Katarzyna J. Stanienda ${ }^{1}$
}

Accepted: 16 March 2016/Published online: 7 April 2016

(c) The Author(s) 2016. This article is published with open access at Springerlink.com

\begin{abstract}
This article presents the results of the studies of Triassic carbonate rock samples taken from the area of the Polish part of the Germanic Basin. The task of the study was the identification of carbonate phases with magnesium: a low-Mg calcite, a high-Mg calcite, a dolomite and a huntite in samples collected from the formations which build the profile of the Lower Muschelkalk in the Polish part of the Germanic Basin. The formations are named Gogolin Beds, Górażdże Beds, Dziewkowice Beds and Karchowice Beds. The mineral phases were described on the basis of the results of the following researches: microscopic analysis, X-ray diffraction, FTIR spectrometry and microprobe measurements. Low-Mg calcite which dominates in the limestones can be demonstrated as follows: $\left(\mathrm{Ca}_{1.00-0.98}, \mathrm{Mg}_{0-0.02}\right)$. In some samples, there is also a higher quantity of dolomite and lower amount of high$\mathrm{Mg}$ calcite. The chemical formula of high-Mg calcite of Gogolin limestones can be demonstrated as $\mathrm{Ca}_{0.9} \mathrm{Mg}_{0.1}$ $\mathrm{CO}_{3}$, whereas in high-Mg calcite of Górażdże limestones the relation assumes the form of $\left(\mathrm{Ca}_{0.92-0.90}, \mathrm{Mg}_{0.08-0.10}\right)$ $\mathrm{CO}_{3}$. The chemical formula of high-magnesium calcite of Dziewkowice limestones is $\left(\mathrm{Ca}_{0.77-0.60}, \mathrm{Mg}_{0.23-0.40}\right) \mathrm{CO}_{3}$ and that of Karchowice limestones is $\left(\mathrm{Ca}_{0.73-0.68}\right.$,- $^{-}$ $\left.\mathrm{Mg}_{0.27-0.32}\right) \mathrm{CO}_{3}$. Moreover, dolomite and huntite were identified in some samples. The content of $\mathrm{Ca}$ and $\mathrm{Mg}$ in dolomite is $\left[\mathrm{Ca}_{0.53-0.51}, \mathrm{Mg}_{0.47-0.49} \mathrm{CO}_{3}\right]$ and in huntite $\left[\mathrm{Ca}_{0.48-0.40}, \mathrm{Mg}_{0.52-0.60} \mathrm{CO}_{3}\right]$. The results of researches extend the data connected with mineral phases which build
\end{abstract}

Katarzyna J. Stanienda

Katarzyna.Stanienda@polsl.pl

1 Department of Mining and Geology, Faculty of Mining and Geology, Institute of Applied Geology, Silesian University of Technology, ul. Akademicka 2, 44-100 Gliwice, Poland
Triassic carbonate rocks of the Germanic Basin. These sediments also occur in other countries of Europe, so that the data can be compared with information connected with the mineral composition of Triassic carbonate rocks situated in other places in the world.

Keywords Muschelkalk limestones - Calcite phases . Dolomite $\cdot$ Huntite

\section{Introduction}

Triassic limestones from the area of the Polish part of the Germanic Basin (the southwestern part of Poland-Opole Silesia) are the sediments of the eastern part of this epicontinental basin. This area is the eastern zone of Central Europe The other parts of the Triassic intracratonic basin are located in Germany, Netherlands, Slovakia, Hungary, Austria, Italy and Switzerland (Feist-Burkhard et al. 2008; Szulc 1990, 2000). The Muschelkalk limestones of the Polish area of the Germanic Basin include carbonate phases varying in $\mathrm{Mg}$ content. The aim of this paper is to show the results of research that allowed to confirm the presence of carbonate phases that vary in terms of $\mathrm{MgCO}_{3}$ contentlow-magnesium calcite, high-Mg calcite, dolomite and huntite in the analyzed sediments. The results of previous studies show that the Triassic limestones of the Polish part of the Germanic Basin are mainly built of not only lowmagnesium calcite, but also high-Mg calcite (high-magnesium calcite called also high-magnesio-calcite) and dolomite occur in them. Moreover lesser amounts of huntite, ankerite and siderite (Stanienda 2006, 2013a, b; Szulc 1990, 2000) were determined. Low-Mg calcite and dolomite are typical for Muschelkalk sediments, but high-Mg calcite and huntite are not. High-Mg calcite is an 
unstable carbonate phase and, just like aragonite, is transformed into low-Mg calcite during early stage of diagenesis (Boggs 2010; Deer et al. 1962), so it occurs in sediments of younger geologic periods. Huntite could be found in different types of rocks. In sedimentary deposits, this carbonate phase occurs usually in the rocks of the vadose zone (Deelman 2011).

Variability in $\mathrm{Ca}$ and $\mathrm{Mg}$ contents was observed in limestones of all formations of the Lower Muschelkalk period-in Gogolin Beds situated in the bottom of the profile; in the next formation-Górażdże Beds; in the following one-Dziewkowice Beds (called also Terebratula); and in Karchowice Beds-the upmost formation of profile. The formation names are regional and come from the names of towns. The variability of $\mathrm{Ca}$ and $\mathrm{Mg}$ content is not typical only for a vertical profile, but also for inside zones of each formation (Stanienda 2006, 2011, 2013a, b; Szulc 1990, 2000).

The research of carbonate phases rich in magnesium is necessary to determine the sources of these chemical elements. They are also important for studying the conditions of formation of carbonate minerals in sediments in the Germanic Basin and also the stability and solubility of minerals. Seawaters and sometimes freshwaters are usually the sources of magnesium. Magnesium could also come from weathering of land carbonate or silicate rocks. When delivered to seawater in a shelf zone, it usually forms dolomite and sometimes high-Mg calcite (Mackenzie and Andersson 2013; Morse and Mackenzie 1990). The stability of the carbonate phase that includes magnesium is usually connected with varying cationic sizes of $\mathrm{Ca}$ and $\mathrm{Mg}$, the length of ionic radius and the strength of the ionic bonds. The strength of the ionic bond between two $\mathrm{Ca}$ ions is higher than that between $\mathrm{Ca}$ and $\mathrm{Mg}$ ions. Therefore, the crystals of carbonates with $\mathrm{Mg}$ substitutions (high-Mg calcites) have weaker stability than calcite without substitution, stoichiometric dolomite or huntite. High-Mg calcite is an unstable carbonate phase in comparison to low-Mg calcite, so it may lose its magnesium in time and alter to low-Mg calcite (Tucker and Wright 1990). If it is exposed to magnesium-rich pore waters, high-Mg calcite can gain additional magnesium and be replaced by dolomite (Boggs 2010). Calcite with $1.9 \mathrm{~mol} \%$ amount of $\mathrm{MgCO}_{3}$ is stable in comparison to both low-Mg calcite and aragonite at temperatures of $25-64{ }^{\circ} \mathrm{C}$. High-Mg calcite, characterized by the content of up to $15 \mathrm{~mol} \%$ of $\mathrm{MgCO}_{3}$, is stable in comparison to low- $\mathrm{Mg}$ calcite at temperatures greater than $42{ }^{\circ} \mathrm{C}$ (up to $60^{\circ} \mathrm{C}$ ) (Bertram et al. 1991). The substitution of $\mathrm{Mg}$ influences the solubility of calcite phases. It rises with an increase of $\mathrm{MgCO}_{3}$ (Morse et al. 2006). High-magnesium calcite, which includes up to $40 \%$ of $\mathrm{MgCO}_{3}$ (Zhang et al. 2010), can be observed in many natural low-temperature environments (Böttcher et al.
1997; Fairbridge 1957). The sea organisms-shells and different parts of skeletons - could be also built of carbonates with magnesium (Böttcher et al. 1997; Böttcher and Dietzel 2010; Boggs 2010; Deer et al. 1962; Nürnberg et al. 1996; Morse and Mackenzie 1990; Morse et al. 2006). Namely, they built skeletons of Crinoids (Goffredo et al. 2012; Nash et al. 2011). Summarizing, low-magnesium calcite has the chemical formula as follows: $\left(\mathrm{Ca}_{1.00-0.97}\right.$, $\left.\mathrm{Mg}_{0-0.03}\right) \mathrm{CO}_{3}$, without considering the substitution of other elements, apart from magnesium (Deer et al. 1962). Mg content in high-magnesium calcite may vary as it is presented in its chemical formula: $\left(\mathrm{Ca}_{0.96-0.51}, \mathrm{Mg}_{0.04-0.49}\right)$ $\mathrm{CO}_{3}$. In dolomite and huntite, magnesium does not substitute calcium. It is the element which builds these carbonate phases together with $\mathrm{Ca}$, in established proportion, so that they are stable carbonate phases. The content of $\mathrm{Ca}$ and $\mathrm{Mg}$ elements in the dolomite structure (chemical formula $\left.(\mathrm{Ca}, \mathrm{Mg})\left(\mathrm{CO}_{3}\right)_{2}\right)$ can be presented as follows $\left[\mathrm{Ca}_{0.5}, \mathrm{Mg}_{0.5} \mathrm{CO}_{3}\right]$ and in the huntite structure (chemical formula $\mathrm{CaMg}_{3}\left[\mathrm{CO}_{3}\right]_{4}$ ) as follows: $\left[\mathrm{Ca}_{0.25}, \mathrm{Mg}_{0.75} \mathrm{CO}_{3}\right]$ (Böttcher et al. 1997; Deer et al. 1962). The formation of dolomite phase depends mainly on the $\mathrm{Mg} / \mathrm{Ca}$ ratio, temperature, $\mathrm{CO}_{2}$ content and reaction time (Mackenzie and Andersson 2013; Morse and Mackenzie 1990; Radha et al. 2012; Tucker and Wright 1990). Protodolomite is usually formed during sediment compaction and the early stages of diagenesis. It is a non-stoichiometric, poorly ordered carbonate phase which often has lower content of $\mathrm{Mg}$ than is typical for stoichiometric dolomite. It usually forms euhedral crystals, rhombohedral in shape (Boggs 2010; Morse and Mackenzie 1990; Tucker and Wright 1990). Typical dolomite, stoichiometric in its chemical composition $\left(13.18 \%\right.$ of $\mathrm{Mg}, 45.91 \%$ of $\mathrm{MgCO}_{3}$ ), is formed during advanced stages of diagenesis, in water environment rich in magnesium. Huntite is a specific carbonate phase with an increased content of magnesium which can occur in rocks of various types such as magmatic, sedimentary and metamorphous rocks, in sediments of various geological periods (Faust 1953). Huntite is usually formed as an effect of hydrothermal processes, weathering of dolomite, or as a result of the transformation of magnesium calcite under high temperature conditions. In sedimentary rocks, it occurs in the sediments of the vadose zone (Deelman 2011; Deer et al. 1962; Faust 1953).

Therefore, it was necessary in this paper to confirm the presence of carbonate phases which vary in terms of the content of magnesium. It allowed obtaining new data on the conditions of Muschelkalk rocks deposition in the Polish part of the Germanic Basin (area of Opole Silesia). According to previous studies, the differentiation of Muschelkalk sediments is the effect of deposition conditions in the Germanic Basin (Feist-Burkhard et al. 2008; Szulc 1990, 2000). These sediments were formed in the 
changeable environment of sea transgressions and regressions. The variability of $\mathrm{Ca}$ and $\mathrm{Mg}$ amounts characteristic for carbonate rocks of Opole Silesia is related to the presence of carbonate phases rich in magnesium. The mineral composition of carbonates of the Triassic period, not only these from the area of Opole Silesia (the southwestern part of Poland), but also the rocks from Upper Silesia (central area of the southern part of Poland) (Stanienda et al. 2012), could also be modified during diagenetic processes. These processes caused some transformations in the primary carbonate phases and formation of new ones.

The results of the studies presented in this paper, especially the information about carbonate phases rich in magnesium, allowed to extend the data connected with mineral composition of carbonate rocks from the Polish part of the Germanic Basin (the southwestern part of Poland - the area of Opole Silesia).

\section{Sampling sites and methodology}

The studied samples were collected in the eastern part area of the Germanic Basin. It is the territory of the Opole Silesia, which is situated in the southwestern part of Poland (Fig. 1). The total thickness of the Lower Muschelkalk sediments varies from 80 to $100 \mathrm{~m}$. The profile of Lower Muschelkalk in this area is built of the rocks of Gogolin Beds (situated at the bottom rocks), then in sequence:

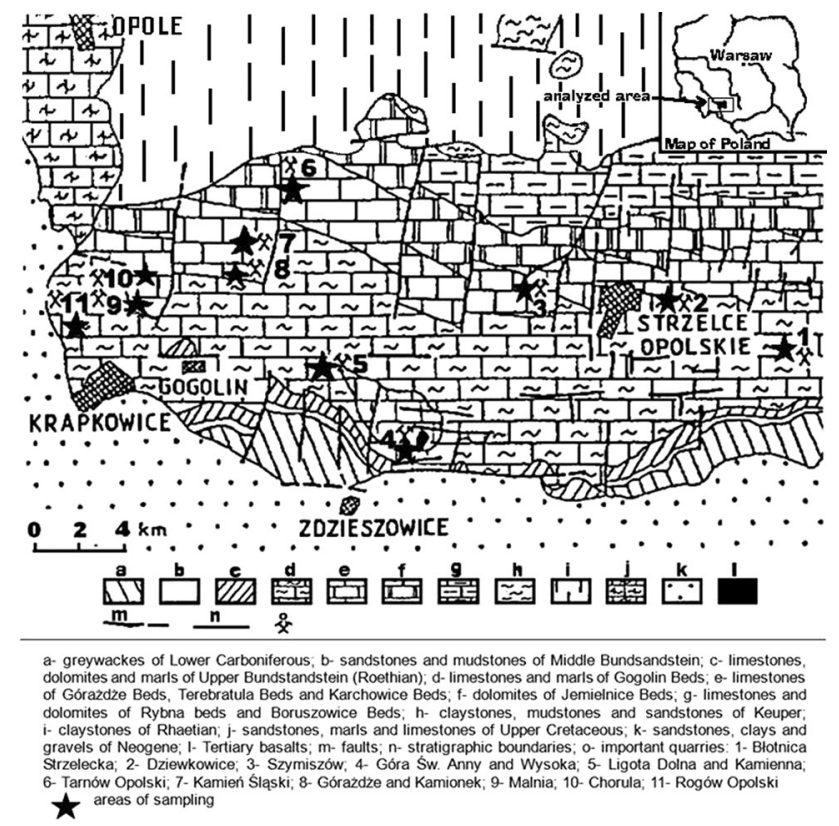

Fig. 1 Simplified geological map of the central part of Opole Silesia-SW part of Poland with sampling location (according to Niedźwiedzki, 2000, modified by Stanienda 2013a)
Górażdże Beds, Dziewkowice (Terebratula) Beds and Karchowice Bed (situated on the top). The thickness of Gogolin Beds varies from 45 to $60 \mathrm{~m}$. The strata are built mainly of banded limestone and marl limestone. The thickness of Górażdże Beds varies from 22 to $25 \mathrm{~m}$. This formation includes thick bedded limestone with interlayers of marl and banded limestone. The total thickness of Dziewkowice Beds is $14 \mathrm{~m}$. The strata are built mainly of marl limestone and marl. The thickness of Karchowice Beds varies from 10 to $35 \mathrm{~m}$ in the northern and western zones of the analyzed area. This formation includes porous limestone, sometimes dolomitized and susceptible to Karst processes.

Samples were taken from the following quarries: Strzelce Opolskie, Szymiszów, Wysoka, Ligota Dolna, Gogolin and from the area of Saint Anne Mountain. 99 samples were taken from all those places. The results of the studies of 15 samples are presented in this article. Three samples were selected from Strzelce Opolskie Quarry (SO1, SO14 and SO20), three from Szymiszów Quarry (S2, S7 and S9), two from Wysoka Quarry (W1 and W14), two from Ligota Dolna Quarry (LD19 and LD20), three from Gogolin Quarry (G1, G2 and G6) and two from Saint Anne Mountain (SA3 and SA5). These are representative samples collected from all of the Lower Muschelkalk formations: Gogolin Beds (samples G1, G2 and G6), Górażdże Beds (samples LD19, LD20, W1, W14 and SA5), Dziewkowice (Terebratula) Beds (samples SO1, S2, S7 and S9) and Karchowice Beds (SO14, SO20 and SA3).

15 samples representative for all formations of Lower Muschelkalk were studied using a petrographic microscope with polarized transmitted light. Selected samples were studied using X-ray diffraction, Fourier spectroscopy (FTIR) and microprobe measurements.

The microscopic analysis was executed using an Opton Axioplan Universal Microscope contacted with K300 Image Analyser, produced by Zeiss.

$\mathrm{X}$-ray diffraction was applied to examine eight selected samples altogether: two samples from Gogolin Beds (G1, G2), two samples from Górażdże Beds (SA5, W1), two samples from Dziewkowice (Terebratula) Beds (S2, S7) and two samples from Karchowice Beds (SO14, SO20). The X-ray diffraction analysis was carried out at the Institute of Applied Geology in Gliwice using the diffractometer HZG4, applying a copper lamp with a nickel screen and the following analysis conditions: voltage $35 \mathrm{kV}$, intensity $18 \mathrm{~mA}$. The method of reflective light was applied here. Dronek Software was used for the evaluation. $\mathrm{X}$-ray diffraction patterns were described using data books containing mineral powder diffraction files (Bayliss et al. 1986a, b).

The Fourier analysis in the infrared spectrum (FTIR) was applied to investigate eight selected samples: two 
samples from Gogolin Beds (G1, G6), two from Górażdże Beds (SA5, W1), two of Dziewkowice (Terebratula) Beds (SO1, S2) and two from Karchowice Beds (SO14, SO20). This method uses selective absorption of light by minerals. The studies were carried out at the Institute of Geological Sciences of the Jagiellonian University using an FTS 135 BioRad Fourier spectrometer. The spectra were elaborated using the software provided by the manufacturer (Bio-Rad Sadtler Division 1981-1993).

Microprobe measurements were applied to investigate the five selected samples: one sample from Gogolin Beds (G1), one from Górażdże Beds (SA5), one from Dziewkowice (Terebratula) Beds (S2) and two from Karchowice Beds (SO14, SO20). These are representative samples for the studied Lower Muschelkalk formations. The studies were carried out at the Institute of Non-ferrous Metals in Gliwice. The analyses were conducted using the techniques of X-ray microanalysis EPMA, with the application of a JXA-8230 X-ray microanalyser manufactured by JOEL. The examinations were performed on polished sections which were sputtered with a carbon coat. The analysis with the application of WDS spectrometers was carried out in microareas of all four samples. The WDS method was applied to conduct quantitative analyses in microareas, in selected points having different chemical compositions. The content of the following chemical elements was determined: $\mathrm{Mg}, \mathrm{Si}, \mathrm{Al}, \mathrm{Ca}, \mathrm{K}, \mathrm{Ba}, \mathrm{Sr}, \mathrm{Fe}, \mathrm{Mn}$, as well as the content of $\mathrm{O}$ and $\mathrm{C}$. Because carbonates burn during exposure to $\mathrm{X}$-rays and the samples were sputtered with a carbon coat, it was necessary to calculate the values of $\mathrm{O}$ and $\mathrm{C}$ to normalize the results of measurements to a value of $100 \%$. The calculation of $\mathrm{O}$ and $\mathrm{C}$ allowed to determine the real contents of these elements, since the results of the rest of the chemical element measurements are original data. The total amount of $\mathrm{C}$ and part of the oxygen formed carbonates. The rest of the $\mathrm{O}$ formed aluminosilicates and quartz. Moreover, the EDS method was applied to conduct quantitative analysis in the second microarea of sample SO14. The X-ray map of the investigated microarea was made using an EDS spectrometer with the magnification of $500 \times$ (imaging area $240 \mu \mathrm{m} \times 170 \mu \mathrm{m})$ as well as element spectra at the measurement points. The content of the following elements was determined: $\mathrm{O}, \mathrm{C}, \mathrm{Mg}, \mathrm{Ca}$ and $\mathrm{Fe}$.

\section{Results of the study}

\section{Microscopic description}

The results of the microscopic analysis allowed to distinguish only two carbonate phases in the studied rocks: calcite and dolomite. The calcite phase includes low- magnesium calcite and high- $\mathrm{Mg}$ calcite because these two phases were impossible to distinguish, since they present the same optical properties. Micritic grains of high-Mg calcite mixed with low-magnesium calcite usually form rock mass in limestones poor in allochems-bioclasts (sample G1 Fig. 2a, sample S2, sample S9-Fig. 2f, sample SO20) and cement which compounds bioclasts (sample LD19, sample LD20-Fig. 2b, sample W14-Fig. 2c, sample SA5-Fig. 2e). Bigger, low-magnesium sparry calcite grains often form veins or aggregates (sample G1-Fig. 2a, sample G2-Fig. 2b, sample W1, sample W14-Fig. 2C, sample SA3-Fig. 2d, sample S2). They are usually different in shape and size. Those are probably secondary calcite - a product of diagenetic processes, aggradation and recrystallization of primary micritic crystals. In some lowmagnesium calcite crystals, rhombohedral cleavage (sample SA3-Fig. 2d) is visible. Calcite crystals often form palisade cement which surrounds allochems (sample LD19, sample LD20-Fig. 2b). Bioclasts are usually filled with micritic calcite (sample LD19, sample LD20-Fig. 2b, sample SA5-Fig. 2e). Stem plates dominate among bioclast shells and fragments of Crinoids. The presence of Crinoids indicate the shelf environment (Flügel 2004). The investigated limestones represent a primary packstone type, which was formed in shallow basin. This type of limestone indicates in-place degradation or deposition subsequent to transport (Flügel 2004). It was impossible to distinguish dolomite and huntite using petrographic microscope. All sparry rhombohedral crystals were treated as a dolomite phase. These crystals were usually well visible in thin sections of the investigated samples (sample G1-Fig. 2a, sample G2, sample S9-Fig. 2f, sample SO14, sample SO20). In some samples, dolomite pseudomorphs (sample S9-Fig. 2f) were observed, which are products of diagenetic processes-i.e., calcitization (dedolomitization) of dolomite crystals. Some of them are filled in with iron oxides. The results of the microscopic study show that in most of the investigated limestones, calcite phases dominate with the exception of sample SO14. This sample (Karchowice limestone) is built mainly of the dolomite phase. Dolomite is present in the rocks of all formations of Lower Muschelkalk. Higher content of the dolomite phase was observed in Dziewkowice Beds and especially in Karchowice Beds (formations of the upper part of the analyzed profile) and lower in Gogolin and Górażdże Beds (formations of the lower part of the analyzed profile).

\section{Results of X-ray diffraction}

The results of X-ray diffraction indicate that four carbonate phases are present in almost all examined samples: lowmagnesium calcite (low-Mg calcite), high-Mg calcite, dolomite and huntite (Fig. 3). The exceptions are: sample 

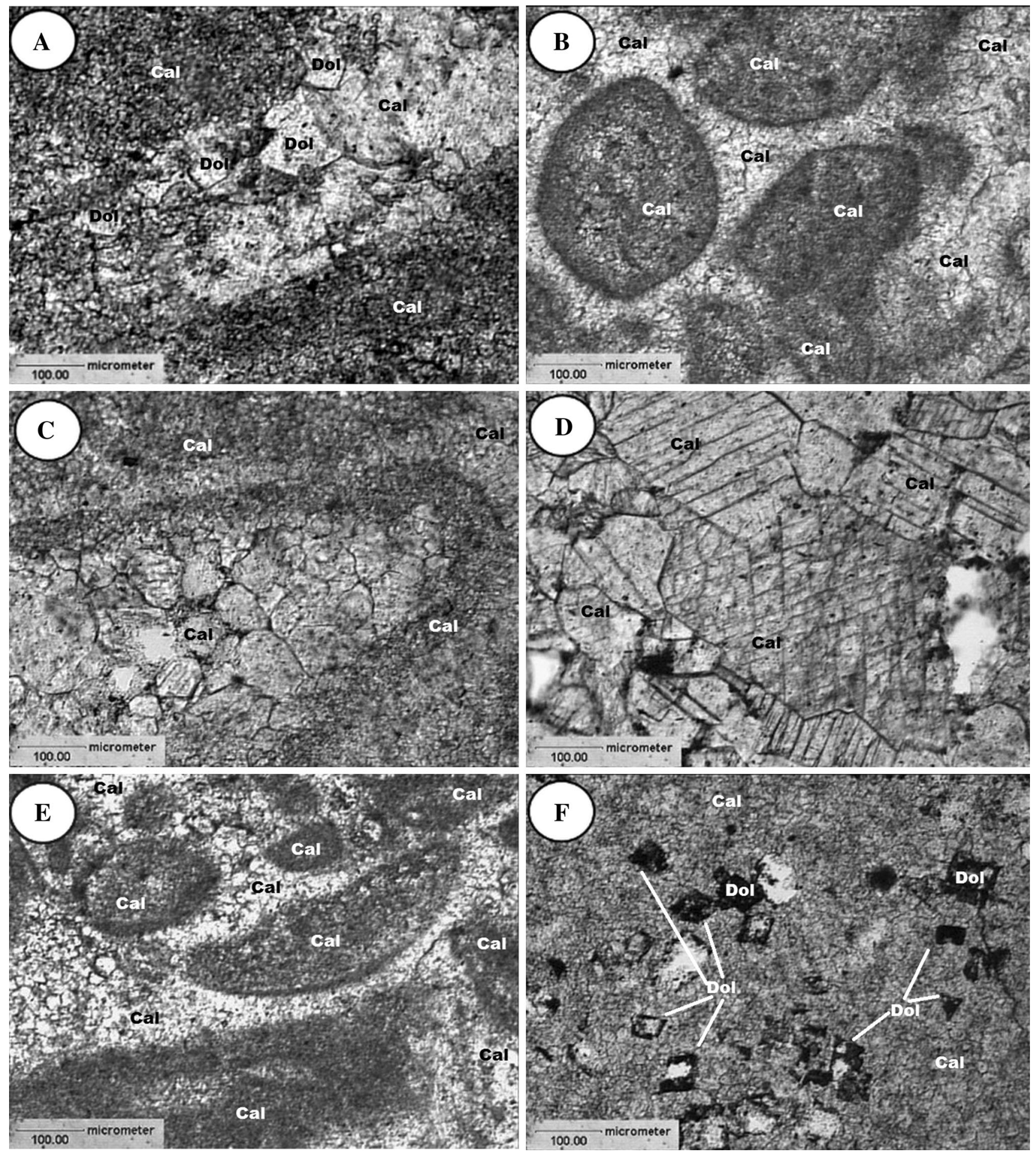

Fig. 2 a Microscopic view of sample G1, $1 \mathrm{~N}$, magn. $\times 100$. b Microscopic view of sample LD20, 1N, magn. $\times 100$. c Microscopic view of sample W14, $1 \mathrm{~N}$, magn. $\times 100$. d Microscopic view of sample

SA3, $1 \mathrm{~N}$, magn. $\times 100$. e Microscopic view of sample SA5, $1 \mathrm{~N}$, magn. $\times 100 . \mathbf{f}$ Microscopic view of sample S9, $1 \mathrm{~N}$, magn. $\times 100$

S2 in which dolomite was not identified and sample SA5. In the X-ray diffraction pattern of the sample SA5, only one low-intensity diffraction line was identified, so the presence of dolomite in this sample is doubtful. For most of

the samples, low-magnesium calcite is the dominant phase with the exception of sample SO14, in which dolomite dominates (Fig. 3d). The content of the dolomite phase is approximately $50 \%$. There is a smaller amount of high-Mg 

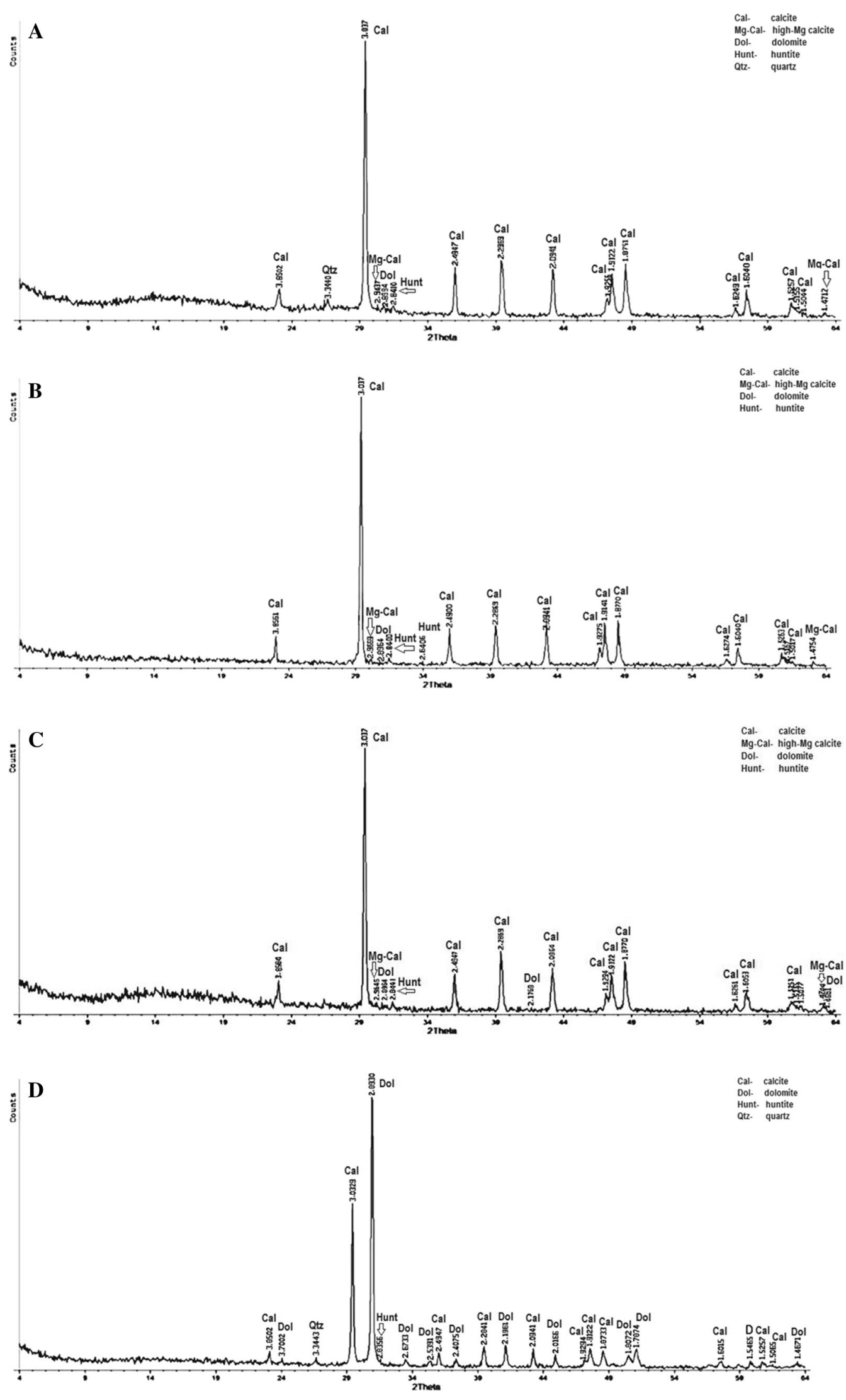
4Fig. 3 a X-ray diffraction pattern of sample G2-Gogolin limestone from Gogolin. b X-ray diffraction pattern of W1 sample-Górażdże limestone from Wysoka. c X-ray diffraction pattern of sample S7Dziewkowice limestone from Szymiszów. d X-ray diffraction pattern of sample SO14-Karchowice limestone from Strzelce Opolskie

calcite in the examined rocks. This carbonate phase was identified in almost all samples (apart from a sample SO14-Fig. 3d), based principally on the diffraction line of the highest intensity (Fig. 3a-c), which presents values of $d_{104}$ from 2.9497 to $2.9669 \AA$ (Böttcher et al. 1997; Zhang et al. 2010). In the diffractogram of sample S2 (Dziewkowice limestone), apart from the diffraction line of the highest intensity, three other diffraction lines of lower intensities typical for high-Mg calcite phase were also determined. In diffractograms of seven samples (samples G1, G2-Fig. 3a, SA5, W1-Fig. 3b, S2, S7-Fig. 3c, SO20), apart from the diffraction line of the highest intensity, one more diffraction line of lower intensity typical for high-Mg calcite phase was also determined (Fig. 3a-c). Huntite appears in small amounts in all examined samples (Fig. 3). It was identified based principally on the diffraction line of the highest intensity (Dollase and Reeder 1986; http://webmineral.com/data/Huntite. shtml). It is usually easier to identify carbonate phases such as calcite and dolomite, which dominate in the carbonate mixture, than other carbonate phases (Pawloski 1985). That is way in most of the diffractograms huntite was identified based principally on the one diffraction line with the highest intensity typical for that phase (Fig. 3). Only in case of one sample (W1-Fig. 3b), one more diffraction line of lower intensity typical for the huntite phase was determined, apart from the diffraction line of the highest intensity. The presence of quartz was determined in the diffractograms of some samples (G2-Fig. 3a, SA5, SO14-Fig. 3d, SO20). In the diffractogram of the sample $\mathrm{S} 2$, illite was also determined. The results of X-ray diffraction show that generally calcite phases dominate in limestones of all Muschelkalk formations. There are smaller amounts of dolomite phases in the examined rocks with the exception of sample SO14 in which dolomite dominates, which confirms the results of the microscopic studies.

\section{Results of FTIR spectroscopy}

The minerals forming constituent parts of the examined limestones, particularly carbonate phases, were identified based on the absorption spectra obtained from the Fourier analysis in the infrared spectrum (Fig. 4). Carbonate minerals are characterized by highly anisodesmic bonds. Anion $\mathrm{CO}_{3}{ }^{2-}$ in the minerals in which atoms have covalent bonds behave like vibrators, with little dependence on the surroundings. Their vibrations, in principle, influence the absorption spectra of carbonates. The absorption bands, in relation to the intramolecular vibrations of $\mathrm{CO}_{3}{ }^{2-}$ anions, correspond to the basic infrared range and the lattice vibrations yield absorption bands in the far infrared (Ahn et al. 1996; Pokrovsky et al. 2000; Ramseyer et al. 1997).

In the analyzed samples, low-magnesium calcite predominates. It was identified in most of the samples, mainly based on the infrared bands $V_{4}=712 \mathrm{~cm}^{-1}$, $V_{2}=847 \mathrm{~cm}^{-1}$ and $V_{2}$-values from 872 to $874 \mathrm{~cm}^{-1}$, $V_{3}$-values from 1415 to $1422 \mathrm{~cm}^{-1}, V_{1}+V_{4}$-values from 1797 to $1799 \mathrm{~cm}^{-1}, V_{1}+V_{3}$-values from 2512 to $2513 \mathrm{~cm}^{-1}$ and some infrared bands of further infrared (Ahn et al. 1996; Pokrovsky et al. 2000; Ramseyer et al. 1997). Values of absorption bands of high-magnesium calcite are usually higher than those of low-Mg calcite (low-magnesium calcite) and lower than the values typical for dolomite (Ahn et al. 1996; Böttcher et al. 1997; Ji et al. 2009; Pokrovsky et al. 2000). It can be stated that highmagnesium calcite is present in the following investigated samples-G6 (Fig. 4a), SO14 (Fig. 4d) and SO20, except for low-magnesium calcite and of dolomite. High-Mg calcite is usually identified based principally on $V_{3}$ absorption band, which has values from 1426 to $1435 \mathrm{~cm}^{-1}$. This phase was identified in sample SO14 by $V_{3}$ absorption band $V_{3}=1426 \mathrm{~cm}^{-1}, V_{1}+V_{3}$ absorption bands $=2519 \mathrm{~cm}^{-1}$ and the absorption band $2626 \mathrm{~cm}^{-1}$ (Fig. 4d). In sample G6, it was identified by $V_{1}+V_{3}$ absorption band $=2519 \mathrm{~cm}^{-1}$. In sample SO20, high-Mg calcite was determined by absorption bands of further infrared with the following values: 1087 and $2356 \mathrm{~cm}^{-1}$. The values of absorption bands which allowed to identify high-Mg calcite are higher than the values typical for low$\mathrm{Mg}$ calcite and lower than the ones, typical for dolomite. The change of the absorption band value can indicate a variable content of magnesium in the crystals of highmagnesium calcite. The increase in the absorption band value indicates an increase in the amount of $\mathrm{Mg}$ ions in the high-Mg calcite crystal structure. Dolomite was identified in six examined rocks: samples G6 (Fig. 4a), SA5, W1 (Fig. 4b), SO1 (Fig. 4c), SO14 (Fig. 4d) and S2. This carbonate phase was determined based principally on the absorption bands of further infrared which are typical for dolomite (Ahn et al. 1996; Pokrovsky et al. 2000; Ramseyer et al. 1997; Stanienda 2013a, b). In sample G6, it was identified by absorption bands with values 2363, 2605 and $2868 \mathrm{~cm}^{-1}$ (Fig. 4a), in sample SA5 by absorption band $2605 \mathrm{~cm}^{-1}$, in sample W1 by absorption bands 1702 and $2605 \mathrm{~cm}^{-1}$ (Fig. 4b), in sample SO1 by absorption bands 1385, 2360 and $2605 \mathrm{~cm}^{-1}$ (Fig. 4c), in sample SO14 by absorption band $2368 \mathrm{~cm}^{-1}$ (Fig. 4d) and in sample S2 by absorption band $2360 \mathrm{~cm}^{-1}$. Huntite was identified in four 
Fig. 4 Infrared absorption spectra of limestone samples in the range from 400 to

$4000 \mathrm{~cm}^{-1}$ (Stanienda 2013a). a Infrared absorption spectrum of sample G6 (Gogolin limestone from Gogolin).

b Infrared absorption spectrum of sample W1 (Górażdże limestone from Wysoka). c Infrared absorption spectrum of sample SO1 (Dziewkowice limestone from Strzelce Opolskie). d Infrared absorption spectrum of sample SO14

(Karchowice limestone from Strzelce Opolskie)
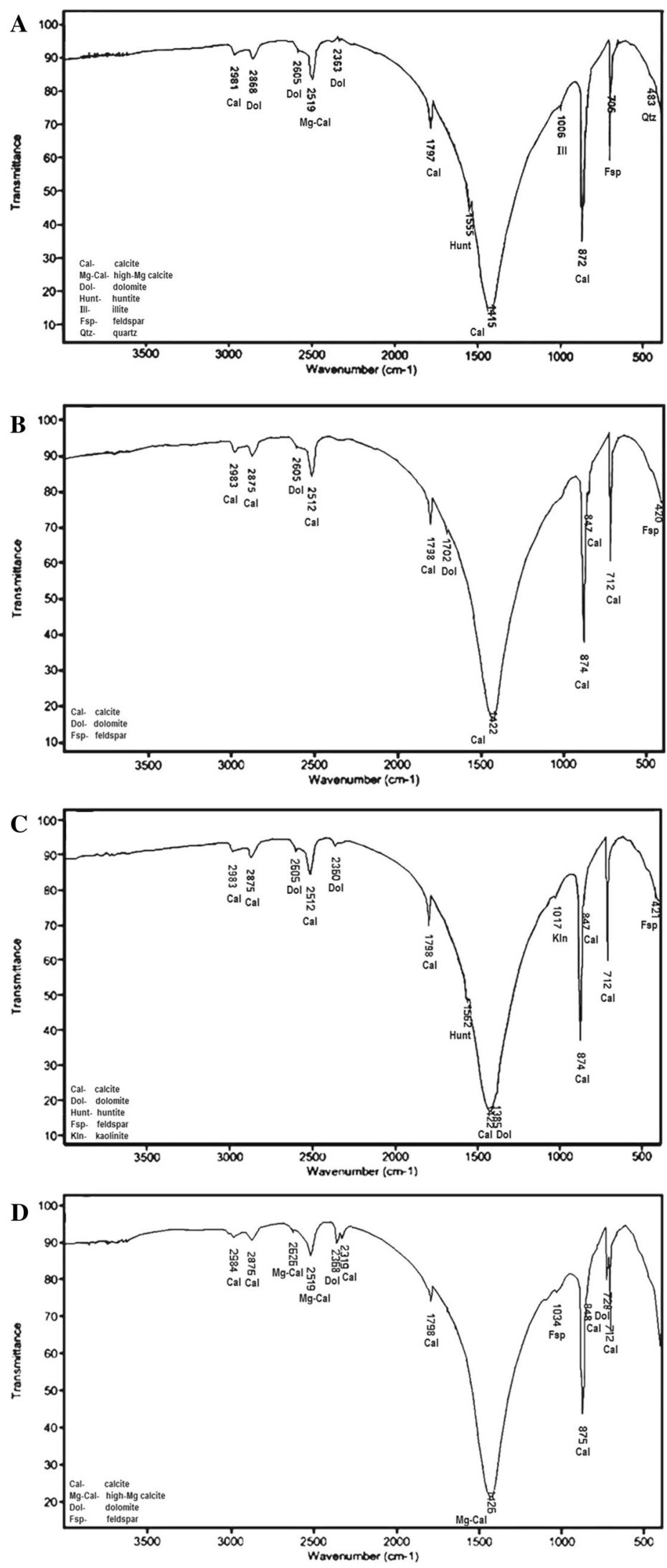
examined rocks: samples G1, G6 (Fig. 4a), SO1 (Fig. 4c) and S2. This carbonate phase, which has higher magnesium content than dolomite, was identified based on the infrared bands with the values: 469 and $800 \mathrm{~cm}^{-1}$ in sample $\mathrm{G} 1$, $1555 \mathrm{~cm}^{-1}$ in samples G6 and S2 (Fig. 4a) and $1562 \mathrm{~cm}^{-1}$ in sample SO1 (Fig. 4c) (Ramseyer et al. 1997; http://rruff. info/Huntite). However, using this analytical method, huntite was identified based only on single bands and only in the limestones of Gogolin and Dziewkowice Beds (Stanienda 2013a, b). The presence of feldspars was determined in the infrared absorption spectra of all samples, G6 (Fig. 4a), SA5, W1 (Fig. 4b), SO1 (Fig. 4c) and SO20 samples have clay minerals and sample G6 has quartz (Fig. 4a) (Stanienda 2013a, b). FTIR spectroscopy allowed to identify high-Mg calcite in rocks of Gogolin Beds and Karchowice Beds, dolomite was found in rocks of Gogolin Beds, Górażdże Beds and Dziewkowice Beds and huntite in rocks of Gogolin Beds and Dziewkowice Beds. The results of this analysis show that low-magnesium calcite dominates in the rocks of all formations.

\section{Results of microprobe measurements}

During the X-ray microanalysis (microprobe measurements), BSE images of representative microareas of the examined samples were taken, and the quantitative chemical composition of the rocks was determined. Measurements were executed in carbonate groundmass. Examples of three representative BSE images of microareas are shown.

WDS analysis was carried out in a microarea of Gogolin limestone (sample G1), WDS analysis was carried out. The results of the measurements are presented in Table 1. The results of chemical analyses carried out in this microarea indicate the occurrence of one carbonate phase: low-magnesium calcite phase (Table 1-points 1-5). The content of $\mathrm{Mg}$ in this phase varies from 0.02 to $0.53 \%$, and the content of $\mathrm{Ca}$ from 40.65 to $41.87 \%$. Therefore, the content of $\mathrm{MgCO}_{3}$ in low-Mg calcite varies from 0.07 to about $1.86 \%$. At all points of this microarea (Table 1), the presence of iron and potassium was recorded. At many points, the presence of manganese was identified and at some points, small amounts of aluminum, barium and silica.

WDS analysis was also carried out in a microarea of Górażdże limestone (sample SA5). The results of the measurements are presented in Table 2. The results of the chemical analyses carried out in this microarea also indicate in this sample the occurrence of one carbonate phase: low-magnesium calcite phase (Table 2-points 1-3). The content of $\mathrm{Mg}$ in this phase varies in points from 0.05 to $0.26 \%$, and the content of $\mathrm{Ca}$ from 43.84 to $45.63 \%$. Therefore, the content of $\mathrm{MgCO}_{3}$ in low-Mg calcite varies from 0.18 to $0.91 \%$ approximately. At many points of this microarea (Table 2), the presence of iron, aluminum and manganese were determined. At one point, the presence of barium and strontium was determined. The presence of strontium and barium confirms the original occurrence of aragonite in these rocks, which is an unstable carbonate phase that was transformed into low-magnesium calcite during diagenetic processes.

WDS analysis was carried out in a microarea of sample S2 (Dziewkowice limestone) (Stanienda 2013a). The electron image of this microarea is presented in Fig. 5a. The results of the measurements are presented in Table 3 . This phase, enriched in magnesium in this microarea, constitutes only about $15 \%$ of the microarea surface. This rock is characterized by a diversified chemical composition

Table 1 Microprobe chemical analyses of a sample G1

\begin{tabular}{|c|c|c|c|c|c|c|c|c|c|c|c|c|}
\hline \multirow[t]{2}{*}{ Point number/mineral } & \multicolumn{11}{|c|}{ Type of chemical element [\%mass] } & \multirow[t]{2}{*}{ Total } \\
\hline & O normalized & C normalized & $\mathrm{Mg}$ & $\mathrm{Si}$ & $\mathrm{Al}$ & $\mathrm{Ca}$ & $\mathrm{K}$ & $\mathrm{Ba}$ & $\mathrm{Sr}$ & $\mathrm{Fe}$ & Mn & \\
\hline $\begin{array}{l}1 / \mathrm{Cal} \\
\qquad\left(\mathrm{Ca}_{0.98}, \mathrm{Mg}_{0.02}\right) \mathrm{CO}_{3}\end{array}$ & 55.13 & 3.10 & 0.53 & bld & 0.02 & 40.83 & 0.02 & bld & bld & 0.33 & 0.04 & 100.00 \\
\hline $\begin{array}{l}2 / \mathrm{Cal} \\
\qquad\left(\mathrm{Ca}_{0.99}, \mathrm{Mg}_{0.01}\right) \mathrm{CO}_{3}\end{array}$ & 52.17 & 4.79 & 0.45 & 0.09 & 0.06 & 41.81 & 0.02 & bld & bld & 0.61 & bld & 100.00 \\
\hline $\begin{array}{l}3 / \mathrm{Cal} \\
\qquad\left(\mathrm{Ca}_{0.99}, \mathrm{Mg}_{0.01}\right) \mathrm{CO}_{3}\end{array}$ & 54.19 & 3.98 & 0.40 & bld & bld & 41.32 & 0.01 & 0.04 & bld & 0.05 & 0.01 & 100.00 \\
\hline $\begin{array}{l}\text { 4/Cal } \\
\qquad \mathrm{CaCO}_{3}\end{array}$ & 50.78 & 6.64 & 0.05 & bld & bld & 41.87 & 0.01 & 0.05 & bld & 0.52 & 0.08 & 100.00 \\
\hline $\begin{array}{l}\text { 5/Cal } \\
\mathrm{CaCO}_{3}\end{array}$ & 52.79 & 6.35 & 0.02 & bld & bld & 40.65 & 0.01 & bld & bld & 0.15 & 0.03 & 100.00 \\
\hline
\end{tabular}

bld Below detection limit, Cal low-magnesium calcite 
Table 2 Microprobe chemical analyses of a sample SA5

\begin{tabular}{|c|c|c|c|c|c|c|c|c|c|c|c|c|}
\hline \multirow[t]{2}{*}{ Point number/mineral } & \multicolumn{11}{|c|}{ Type of chemical element [\%mass] } & \multirow[t]{2}{*}{ Total } \\
\hline & O normalized & C normalized & $\mathrm{Mg}$ & $\mathrm{Si}$ & $\mathrm{Al}$ & $\mathrm{Ca}$ & $\mathrm{K}$ & $\mathrm{Ba}$ & $\mathrm{Sr}$ & $\mathrm{Fe}$ & $\mathrm{Mn}$ & \\
\hline $\begin{array}{l}1 / \mathrm{Cal} \\
\quad\left(\mathrm{Ca}_{0.99}, \mathrm{Mg}_{0.01}\right) \mathrm{CO}_{3}\end{array}$ & 46.06 & 9.69 & 0.26 & bld & 0.01 & 43.84 & bld & 0.01 & 0.06 & 0.04 & 0.03 & 100.00 \\
\hline $\begin{array}{l}2 / \mathrm{Cal} \\
\mathrm{CaCO}_{3}\end{array}$ & 45.12 & 8.94 & 0.23 & bld & bld & 45.63 & bld & bld & bld & 0.07 & 0.01 & 100.00 \\
\hline $\begin{array}{l}3 / \mathrm{Cal} \\
\mathrm{CaCO}_{3}\end{array}$ & 46.74 & 8.45 & 0.05 & bld & 0.01 & 44.75 & bld & bld & bld & bld & bld & 100.00 \\
\hline
\end{tabular}

bld Below detection limit, Cal low-magnesium calcite
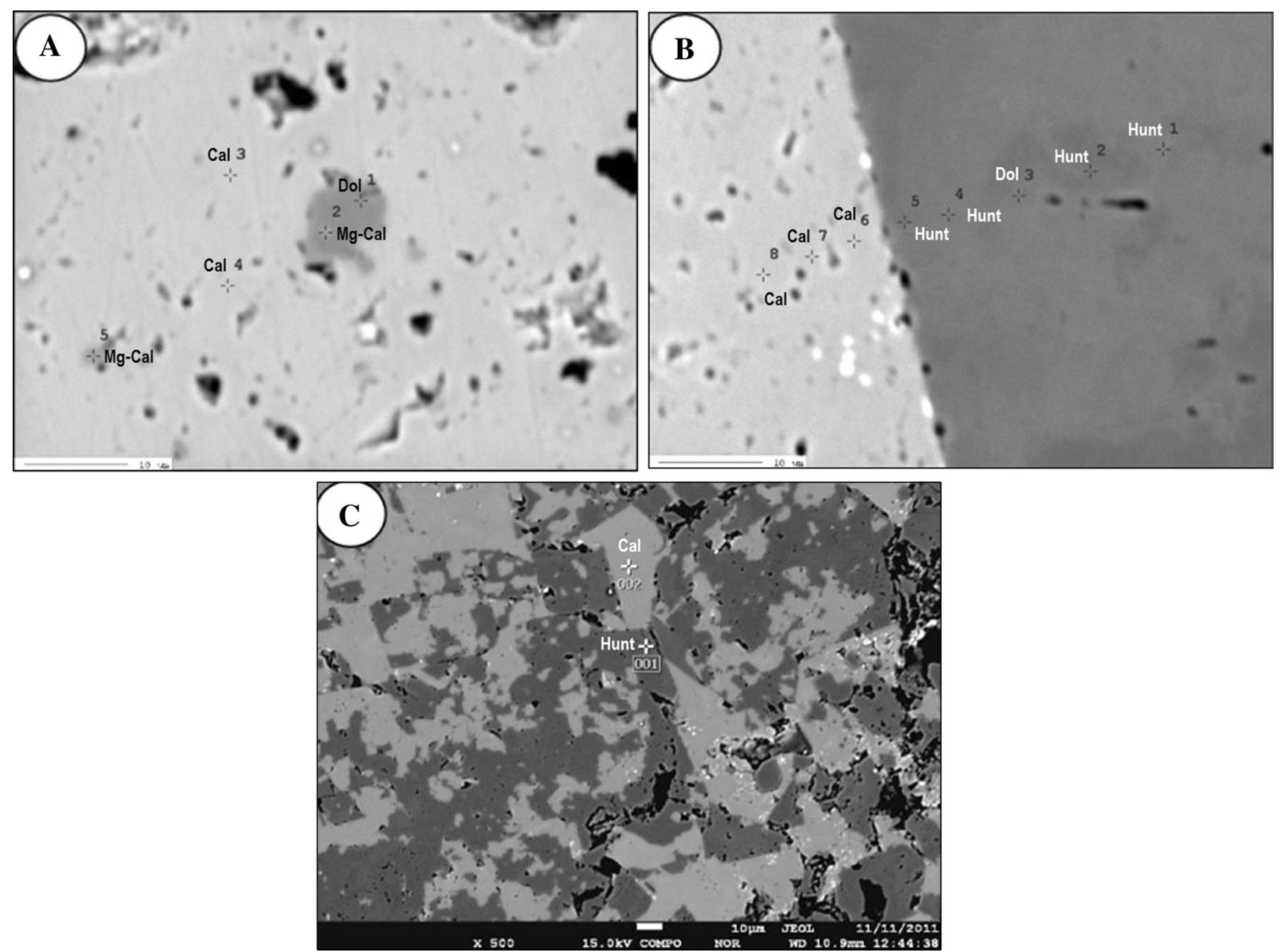

Fig. 5 a BSE image of sample S2 (Dziewkowice limestone from Szymiszów), magn. $\times 2000,1-5$-points of chemical analysis (Stanienda 2013a). b First BSE image of sample SO14 (Karchowice limestone from Strzelce Opolskie), magn. $\times 2000,1-8$-points of

of the carbonate phase due to the content of $\mathrm{Ca}$ and $\mathrm{Mg}$. The enrichment of magnesium occurs in dark gray crystals of the carbonate mass (Fig. 5a-points 1, 2 and 5; chemical analysis (Stanienda 2013b). c Second BSE image of sample SO14 (Karchowice limestone from Strzelce Opolskie), magn. $\times 2000$, 1-2-points of chemical analysis

Table 3-points 1, 2 and 5). The results of the chemical analyses show that in the microarea of sample S2, there are three carbonate phases-low-magnesium calcite 
Table 3 Microprobe chemical analyses of a sample S2 (Stanienda 2013a)

\begin{tabular}{|c|c|c|c|c|c|c|c|c|c|c|c|c|}
\hline \multirow[t]{2}{*}{ Point number/mineral } & \multicolumn{11}{|c|}{ Type of chemical element [\%mass] (Fig. 5a) } & \multirow[t]{2}{*}{ Total } \\
\hline & O normalized & $\mathrm{C}$ normalized & $\mathrm{Mg}$ & $\mathrm{Si}$ & $\mathrm{Al}$ & $\mathrm{Ca}$ & $\mathrm{K}$ & $\mathrm{Ba}$ & $\mathrm{Sr}$ & $\mathrm{Fe}$ & Mn & \\
\hline $\begin{array}{l}\text { 1/Dol } \\
\qquad\left[\mathrm{Ca}_{0.53}, \mathrm{Mg}_{0.47} \mathrm{CO}_{3}\right]\end{array}$ & 53.80 & 8.80 & 13.20 & bld & bld & 24.20 & bld & bld & bld & bld & bld & 100.00 \\
\hline $\begin{array}{l}2 / \mathrm{Mg}-\mathrm{Cal} \\
\quad\left(\mathrm{Ca}_{0.60}, \mathrm{Mg}_{0.40}\right) \mathrm{CO}_{3}\end{array}$ & 54.80 & 8.00 & 10.70 & bld & bld & 26.30 & bld & bld & bld & 0.20 & bld & 100.00 \\
\hline $\begin{array}{l}3 / \mathrm{Cal} \\
\quad\left(\mathrm{Ca}_{0.99}, \mathrm{Mg}_{0.01}\right) \mathrm{CO}_{3}\end{array}$ & 50.60 & 8.00 & 0.30 & bld & bld & 41.00 & bld & bld & 0.10 & bld & bld & 100.00 \\
\hline $\begin{array}{l}4 / \mathrm{Cal} \\
\qquad\left(\mathrm{Ca}_{0.99}, \mathrm{Mg}_{0.01}\right) \mathrm{CO}_{3}\end{array}$ & 46.70 & 11.60 & 0.20 & bld & bld & 41.50 & bld & bld & bld & bld & bld & 100.00 \\
\hline $\begin{array}{l}5 / \mathrm{Mg}-\mathrm{Cal} \\
\quad\left(\mathrm{Ca}_{0.77}, \mathrm{Mg}_{0.23}\right) \mathrm{CO}_{3}\end{array}$ & 45.90 & 8.60 & 7.10 & bld & bld & 38.40 & bld & bld & bld & bld & bld & 100.00 \\
\hline
\end{tabular}

bld Below detection limit, Cal low-magnesium calcite, $\mathrm{Mg}$-Cal high-magnesium calcite, $\mathrm{Dol}$ dolomite

(Table 3-points 3 and 4), high-Mg calcite (Table 3points 2 and 5) and dolomite (Table 3-point 1). In lowmagnesium calcite, the content of $\mathrm{Mg}$ varies from 0.20 to $0.30 \%$, and the content of $\mathrm{Ca}$ from 41.00 to $41.50 \%$. Therefore, the content of $\mathrm{MgCO}_{3}$ in low-Mg calcite varies from 0.70 to $1.05 \%$. The content of $\mathrm{Mg}$ in high- $\mathrm{Mg}$ calcite varies from 7.10 to $10.70 \%$ and the content of $\mathrm{Ca}$ from 26.30 to $38.40 \%$. The amount of $\mathrm{MgCO}_{3}$ in high-Mg calcite present values from 24.85 to $37.45 \%$. It indicates the increased content of $\mathrm{Mg}$ in high-magnesium calcite in sample S2. The content of $\mathrm{Mg}$ in dolomite is $13.20 \%$, and that of $\mathrm{Ca} 24.20 \%$. Therefore, the amount of $\mathrm{MgCO}_{3}$ in dolomite is $46.20 \%$-which is the stoichiometric value of dolomite. The presence of iron and strontium was determined in single points (Table 3). The presence of strontium confirms the original occurrence of aragonite in these rocks, an unstable carbonate phase which was transformed into low-magnesium calcite during diagenetic processes.

WDS analysis was also carried out in microarea 1 of sample SO14 (Karchowice limestone) (Stanienda 2013b). The electron image of this microarea is presented in Fig. 5b. The results of measurements are presented in Table 4. This phase, rich in magnesium, comprises about $70 \%$ of the microarea surface. The carbonate phase of sample SO14 is characterized by diversified chemical composition due to the content of $\mathrm{Ca}$ and $\mathrm{Mg}$. Enrichment in magnesium occurs in dark gray crystals of carbonate mass (Fig. 5b-points from 1 to 5; Table 4-points from 1 to 5). The results of the chemical analyses show that in sample SO14, three carbonate phases occur-low-magnesium calcite (Table 4-points 6-8), dolomite (Table 4point 3 and 4) and huntite (Table 4-points 1, 2, 4 and 5). The content of $\mathrm{Mg}$ in low-magnesium calcite varies from 0.104 to $0.186 \%$, and that of calcium from 41.88 to
$44.02 \%$. Therefore, the amount of $\mathrm{MgCO}_{3}$ in low-Mg calcite varies from 0.36 to $0.65 \%$, approximately. The amount of $\mathrm{Mg}$ in the dolomite is $13.42 \%$ and $\mathrm{Ca} 24.87 \%$. Therefore, the content of $\mathrm{MgCO}_{3}$ in dolomite is $46.97 \%$. It is a little bit higher than the stoichiometric value of dolomite $\left(46.13 \%\right.$ of $\mathrm{MgCO}_{3}$ ). The content of $\mathrm{Mg}$ in huntite varies from 14.01 to $15.92 \%$, and that of calcium from 24.78 to $25.19 \%$. Therefore, the amount of $\mathrm{MgCO}_{3}$ in huntite varies from 49.04 to $55.72 \%$. The results of the study show that the content of $\mathrm{MgCO}_{3}$ in huntite is lower than the stoichiometric value for this carbonate phase, which usually varies from 69.30 to $71.40 \%$ of $\mathrm{MgCO}_{3}$ (Stanienda 2013b). A lower content of $\mathrm{MgCO}_{3}$ in huntite could be caused by diagenetic processes-dehuntization. During this process, the content of $\mathrm{Mg}$ in carbonate minerals with magnesium is reduced. At the points from 1 to 5, at the places where huntite and dolomite occur, higher content of iron was also determined as compared to points 6, 7 and 8, usually indicating the substitution of magnesium in carbonate crystals containing $\mathrm{Mg}$. At many points, the presence of aluminum and manganese was determined and in some points also the presence of potassium, barium and strontium (Table 4). The presence of strontium and barium confirms the original occurrence of aragonite in these rocks, an unstable carbonate phase which was transformed into low-magnesium calcite during diagenetic processes.

In microarea 2 of sample SO14, EDS analysis was carried out at two points having light and dark gray color. Point 1 was selected in the area of a probable occurrence of the carbonate phase enriched in magnesium, and point 2 in the area of the calcite phase. The electron image of this microarea is presented in Fig. 5c. The selected specimen fragment of this Karchowice limestone is built of the calcite carbonate phase in light gray color and of the 
Table 4 Microprobe chemical analyses in the first microarea of sample SO14 (Stanienda 2013b)

\begin{tabular}{|c|c|c|c|c|c|c|c|c|c|c|c|c|}
\hline \multirow[t]{2}{*}{ Point number/mineral } & \multicolumn{11}{|c|}{ Type of chemical element [\%mass] (Fig. 5b) } & \multirow[t]{2}{*}{ Total } \\
\hline & O normalized & C normalized & $\mathrm{Mg}$ & $\mathrm{Si}$ & $\mathrm{Al}$ & $\mathrm{Ca}$ & $\mathrm{K}$ & $\mathrm{Ba}$ & $\mathrm{Sr}$ & $\mathrm{Fe}$ & $\mathrm{Mn}$ & \\
\hline $\begin{array}{l}\text { 1/Hunt } \\
\qquad\left[\mathrm{Ca}_{0.48}, \mathrm{Mg}_{0.52} \mathrm{CO}_{3}\right]\end{array}$ & 48.36 & 11.543 & 14.04 & bld & 0.029 & 25.19 & bld & bld & 0.024 & 0.814 & bld & 100.00 \\
\hline $\begin{array}{l}\text { 2/Hunt } \\
\qquad\left[\mathrm{Ca}_{0.47}, \mathrm{Mg}_{0.53} \mathrm{CO}_{3}\right]\end{array}$ & 47.32 & 12.902 & 14.01 & bld & 0.017 & 24.78 & bld & bld & bld & 0.971 & bld & 100.00 \\
\hline $\begin{array}{l}\text { 3/Dol } \\
\qquad\left[\mathrm{Ca}_{0.53}, \mathrm{Mg}_{0.47} \mathrm{CO}_{3}\right]\end{array}$ & 49.02 & 11.526 & 13.42 & bld & 0.017 & 24.87 & 0.010 & bld & bld & 1.093 & 0.044 & 100.00 \\
\hline $\begin{array}{l}\text { 4/Hunt } \\
\qquad\left[\mathrm{Ca}_{0.46}, \mathrm{Mg}_{0.54} \mathrm{CO}_{3}\right]\end{array}$ & 46.59 & 12.187 & 14.72 & bld & 0.033 & 24.99 & 0.001 & 0.080 & bld & 1.399 & 0.000 & 100.00 \\
\hline $\begin{array}{l}\text { 5/Hunt } \\
\qquad\left[\mathrm{Ca}_{0.48}, \mathrm{Mg}_{0.52} \mathrm{CO}_{3}\right]\end{array}$ & 45.60 & 12.36 & 15.92 & 0.005 & 0.025 & 24.78 & bld & bld & 0.017 & 1.266 & 0.027 & 100.00 \\
\hline $\begin{array}{l}\text { 6/Cal } \\
\quad\left(\mathrm{Ca}_{0.99}, \mathrm{Mg}_{0.01}\right) \mathrm{CO}_{3}\end{array}$ & 42.82 & 14.967 & 0.186 & bld & 0.017 & 41.88 & bld & bld & bld & 0.109 & 0.021 & 100.00 \\
\hline $\begin{array}{l}\text { 7/Cal } \\
\quad\left(\mathrm{Ca}_{0.99}, \mathrm{Mg}_{0.01}\right) \mathrm{CO}_{3}\end{array}$ & 44.71 & 12.495 & 0.159 & bld & bld & 42.53 & bld & bld & bld & 0.106 & bld & 100.00 \\
\hline $\begin{array}{l}8 / \mathrm{Cal} \\
\mathrm{CaCO}_{3}\end{array}$ & 43.18 & 12.445 & 0.104 & bld & bld & 44.02 & bld & 0.008 & bld & 0.238 & 0.005 & 100.00 \\
\hline
\end{tabular}

bld Below detection limit, Cal low-magnesium calcite, Dol dolomite, Hunt huntite

Table 5 Microprobe chemical analyses in the second microarea of sample SO14

\begin{tabular}{lllllll}
\hline Point number/mineral & \multicolumn{2}{l}{ Type of chemical element [\%mass] } & (Fig. 5c) & \multirow{2}{*}{ Total } \\
\cline { 2 - 5 } & O normalized & $\mathrm{C}$ normalized & $\mathrm{Mg}$ & $\mathrm{Ca}$ & $\mathrm{Fe}$ & \\
\hline $\begin{array}{l}001 / \mathrm{Hunt} \\
{\left[\mathrm{Ca}_{0.40}, \mathrm{Mg}_{0.60} \mathrm{CO}_{3}\right]}\end{array}$ & 50.40 & 13.61 & 15.99 & 19.01 & 0.91 & 100.00 \\
$\begin{array}{l}002 / \mathrm{Cal} \\
\mathrm{CaCO}_{3}\end{array}$ & 53.70 & 5.21 & & & & \\
\hline
\end{tabular}

Cal low-magnesium calcite, Hunt huntite carbonate phase enriched in magnesium, having euhedral, rhombohedral fabric of dark gray crystals. It is confirmed by the average chemical composition determined in this microarea (Table 5). The carbonate phase of point 1 (Fig. 5c-point 1) is characterized by a considerable enrichment in magnesium and by increased content of iron, probably due to the substitution of magnesium in the carbonate phase enriched in $\mathrm{Mg}$.

The results of the chemical analyses show that the two carbonate phases occur in this microarea of sample SO14-low-magnesium calcite (Table 5-point 2) and huntite (Table 5-point 1). The content of $\mathrm{Mg}$ in lowmagnesium calcite is $0.08 \%$, and that of $\mathrm{Ca} 41.00 \%$. Therefore, the content of $\mathrm{MgCO}_{3}$ in low-Mg calcite is $0.28 \%$. A high share of $\mathrm{Mg}$ is characteristic for huntite. The content of magnesium in huntite is $15.99 \%$, and that of $\mathrm{Ca} 16.01 \%$. Therefore, the amount of $\mathrm{MgCO}_{3}$ in huntite is $55.97 \%$-lower than the stoichiometric value for this carbonate phase (69.30 to $72.28 \%$ of $\mathrm{MgCO}_{3}$ ). The results of the analyses carried out at point 2 indicate the purity of the calcite phase. The presence of iron was determined at both points, but the amount of $\mathrm{Fe}$ was higher in point 1 (huntite phase) than in point 2 (low-Mg calcite phase).

WDS analysis was also carried out in a microarea of sample SO20 (Karchowice limestone) (Stanienda 2013a). The results of measurements are presented in Table 6 . The phase enriched in magnesium comprises about $10 \%$ of the microarea surface. The carbonate phase of sample $\mathrm{SO} 20$ is characterized by diversified chemical composition due to the content of $\mathrm{Ca}$ and $\mathrm{Mg}$. The results of the chemical analyses show that two carbonate phases occur there-lowmagnesium calcite (Table 6-points 4 and 5) and high-Mg calcite (Table 6-points 1-3). Moreover, the oxide phase was determined (Table 6-points 6 and 7). The content of 
Table 6 Microprobe chemical analyses of a sample SO20 (Stanienda 2013a)

\begin{tabular}{|c|c|c|c|c|c|c|c|c|c|c|c|c|}
\hline \multirow[t]{2}{*}{ Point number/mineral } & \multicolumn{11}{|c|}{ Type of chemical element [\% mass] } & \multirow[t]{2}{*}{ Total } \\
\hline & O normalized & $\mathrm{C}$ normalized & $\mathrm{Mg}$ & $\mathrm{Si}$ & $\mathrm{Al}$ & $\mathrm{Ca}$ & $\mathrm{K}$ & $\mathrm{Ba}$ & $\mathrm{Sr}$ & $\mathrm{Fe}$ & $\mathrm{Mn}$ & \\
\hline $\begin{array}{l}1 / \mathrm{Mg}-\mathrm{Cal} \\
\quad\left(\mathrm{Ca}_{0.73}, \mathrm{Mg}_{0.27}\right) \mathrm{CO}_{3}\end{array}$ & 58.86 & 5.05 & 6.29 & bld & 0.03 & 29.25 & 0.01 & 0.01 & bld & 0.42 & 0.08 & 100.00 \\
\hline $\begin{array}{l}\text { 2/Mg-Cal } \\
\quad\left(\mathrm{Ca}_{0.70}, \mathrm{Mg}_{0.30}\right) \mathrm{CO}_{3}\end{array}$ & 55.21 & 11.09 & 7.51 & 0.03 & 0.09 & 25.73 & 0.02 & 0.01 & 0.02 & 0.24 & 0.05 & 100.00 \\
\hline $\begin{array}{l}\text { 3/Mg-Cal } \\
\quad\left(\mathrm{Ca}_{0.68}, \mathrm{Mg}_{0.32}\right) \mathrm{CO}_{3}\end{array}$ & 54.43 & 9.69 & 8.48 & 0.05 & 0.06 & 26.49 & 0.02 & bld & bld & 0.65 & 0.13 & 100.00 \\
\hline $\begin{array}{l}\text { 4/Cal } \\
\mathrm{CaCO}_{3}\end{array}$ & 54.92 & 5.58 & 0.02 & bld & bld & 39.40 & bld & bld & 0.03 & 0.05 & bld & 100.00 \\
\hline $\begin{array}{l}5 / \mathrm{Cal} \\
\quad\left(\mathrm{Ca}_{0.99}, \mathrm{Mg}_{0.01}\right) \mathrm{CO}_{3}\end{array}$ & 56.11 & 4.70 & 0.19 & bld & 0.02 & 38.81 & 0.01 & bld & 0.05 & 0.11 & bld & 100.00 \\
\hline 6 oxide phase & 42.86 & 5.97 & 0.37 & 2.65 & 2.42 & 6.66 & 0.21 & 0.04 & bld & 38.62 & 0.20 & 100.00 \\
\hline 7 oxide phase & 49.31 & 8.25 & 0.07 & 11.09 & 9.82 & 14.37 & 0.06 & bld & bld & 6.96 & 0.07 & 100.00 \\
\hline
\end{tabular}

bld Below detection limit; Cal low-magnesium calcite; $\mathrm{Mg}$-Cal high-magnesium calcite; oxide phases probably quartz, aluminosilicates (feldspars) and iron hydroxides

$\mathrm{Mg}$ in the low-magnesium calcite varies from 0.02 to $0.19 \%$, and that of calcium from 38.81 to $39.40 \%$. Therefore, the amount of $\mathrm{MgCO}_{3}$ in low-Mg calcite varies from 0.07 to $0.67 \%$, approximately. The content of $\mathrm{Mg}$ in the high-Mg calcite varies from 6.29 to $8.48 \%$, and that of calcium from 25.73 to $29.25 \%$. The results of the study show that the amount of $\mathrm{MgCO}_{3}$ in high-Mg calcite varies from 22.02 to $29.68 \%$. An increased content of silica, aluminum, potassium and iron was determined at points 6 and 7 (Table 6). It is connected with the oxide mineral phase. Silicates (quartz) and aluminosilicates (feldspars) probably occur in this sample. It confirms the results of previous researches, especially the results of FTIR spectroscopy, which indicate the presence of quartz, feldspars and clay minerals in the limestones of Karchowice Beds. The increased content of $\mathrm{Fe}$ indicates a possibility of iron hydroxide presence in these samples. The presence of manganese, barium and strontium was also found in some points. The presence of strontium and barium confirms the original occurrence of aragonite in these rocks, an unstable carbonate phase which was transformed into lowmagnesium calcite during the diagenetic processes.

On the basis of the results of the microprobe measurements, the chemical formulas of the determined carbonate phases were calculated (Table 7). The values of $\mathrm{Ca}$ and $\mathrm{Mg}$ presented in tables 1-6 allowed to calculate $\mathrm{CaO}$ and $\mathrm{MgO}$ contents in the analyzed sample points and also to calculate the amounts of $\mathrm{CaCO}_{3}$ and $\mathrm{MgCO}_{3}$. That data were used to calculate the chemical formulas of the carbonates. The results of microprobe measurements show that the limestones of Gogolin and Górażdże Beds (formations of the lower part of the analyzed profile) are mainly built of low- magnesium calcite. High-Mg calcite occurs in Dziewkowice limestones (first formation of the upper part of the profile) and Karchowice limestones (second formation of the upper part of the profile). Dolomite occurs in limestones of Dziewkowice and Karchowice formations. The calcite phase with an increased content of magnesium of Dziewkowice and Karchowice limestones is high-magnesium calcite. In Karchowice limestones (the top formation of upper part of the analyzed profile), all carbonate phases with magnesium-low-Mg calcite, high-Mg calcite, dolomite and huntite-were determined. According to the results, the content of $\mathrm{MgCO}_{3}$ in low-Mg calcite does not exceed $1.05 \%$. Generally, the amount of $\mathrm{MgCO}_{3}$ in high$\mathrm{Mg}$ calcite varies from 22.02 to $37.45 \%$. The content of magnesium in high- $\mathrm{Mg}$ calcite of Karchowice limestones is lower than the amount of this chemical element in Dziewkowice limestones. The amount of $\mathrm{MgCO}_{3}$ in dolomite varies from $45.93 \%$ in rocks of Dziewkowice Beds to $46.72 \%$ in rocks of Karchowice Beds. Therefore, it can be treated as ordered dolomite. The results show that the amount of $\mathrm{MgCO}_{3}$ in huntite varies from 48.78 to $55.67 \%$. Huntite in the analyzed limestones has lower content of $\mathrm{Mg}$ than the stoichiometric value for this carbonate phase (69.30 to $72.28 \%$ of $\mathrm{MgCO}_{3}$ ). On the basis of the microprobe measurement results, it was possible to compare the $\mathrm{Mg}$ and $\mathrm{Ca}$ values of dolomite and huntite with the stoichiometric values. According to the literature data, the stoichiometric content of $\mathrm{Mg}$ in dolomite is $13.18 \%$ $\left(46.13 \% \mathrm{MgCO}_{3}\right)$, while in huntite it is $20.65 \%(72.28 \%$ $\mathrm{MgCO}_{3}$ )-higher than in dolomite. The content of $\mathrm{Ca}$ in dolomite is $21.73 \%\left(54.33 \% \mathrm{CaCO}_{3}\right)$, while in huntite the present value was $11.35 \%\left(28.38 \% \mathrm{CaCO}_{3}\right)$ (http://www. 
Table 7 Structures of crystal cell and chemical formulas of carbonate phases with magnesium

\begin{tabular}{|c|c|c|c|c|}
\hline No. & $\begin{array}{l}\text { Carbonate } \\
\text { phase name }\end{array}$ & $\begin{array}{l}\text { Chemical formula calculated on the } \\
\text { basis of microprobe measurements }\end{array}$ & $\begin{array}{l}\text { Cell parameters (Althoff 1977; Deer } \\
\text { et al. 1962; Dollase and Reeder 1986) }\end{array}$ & $\begin{array}{l}\text { Space group (Althoff 1977; Deer et al. } \\
\text { 1962; Dollase and Reeder 1986) }\end{array}$ \\
\hline 1 & $\begin{array}{l}\text { Low-Mg } \\
\text { calcite }\end{array}$ & $\begin{array}{l}\text { Gogolin Beds } \\
\left(\mathrm{Ca}_{1.00-0.98}, \mathrm{Mg}_{0.00-0.02}\right) \mathrm{CO}_{3} \\
\text { Górażdże Beds } \\
\quad\left(\mathrm{Ca}_{1.00-0.99}, \mathrm{Mg}_{0.00-0.01}\right) \mathrm{CO}_{3} \\
\text { Dziewkowice Beds } \\
\quad\left(\mathrm{Ca}_{0.99}, \mathrm{Mg}_{0.01}\right) \mathrm{CO}_{3} \\
\text { Karchowice Beds } \\
\left(\mathrm{Ca}_{1.00-0.99}, \mathrm{Mg}_{0.00-0.01}\right) \mathrm{CO}_{3}\end{array}$ & $a_{\mathrm{o}}=4.989 \AA c_{\mathrm{o}}=17.062 \AA$ & Scalenohedral-R3c \\
\hline 2 & $\begin{array}{l}\text { High-Mg } \\
\text { calcite }\end{array}$ & $\begin{array}{l}\text { Gogolin Beds } \mathrm{Ca}_{0.90} \mathrm{Mg}_{0.10} \mathrm{CO}_{3} \\
\quad \text { Stanienda 2013a) } \\
\text { Górażdże Beds } \\
\left(\mathrm{Ca}_{0.92-0.90}, \mathrm{Mg}_{0.08-0.10}\right) \mathrm{CO}_{3} \\
\quad(\text { Stanienda 2013a) } \\
\text { Dziewkowice Beds } \\
\left(\mathrm{Ca}_{0.77-0.60}, \mathrm{Mg}_{0.23-0.40}\right) \mathrm{CO}_{3} \\
\text { Karchowice Beds } \\
\left(\mathrm{Ca}_{0.73-0.68}, \mathrm{Mg}_{0.27-0.32}\right) \mathrm{CO}_{3}\end{array}$ & $a_{\mathrm{o}}=4941 \AA, c_{\mathrm{o}}=16854 \AA$ & Rhombohedral-R3c \\
\hline 3 & Dolomite & $\begin{array}{l}\text { Gogolin Beds not calculated } \\
\text { Górażdże Beds not calculated } \\
\text { Dziewkowice Beds } \\
{\left[\mathrm{Ca}_{0.53}, \mathrm{Mg}_{0.47} \mathrm{CO}_{3}\right]} \\
\text { Karchowice Beds } \\
{\left[\mathrm{Ca}_{0.53-0.51}, \mathrm{Mg}_{0.47-0.49} \mathrm{CO}_{3}\right]}\end{array}$ & $a_{\mathrm{o}}=4.842 \AA, c_{\mathrm{o}}=15.95 \AA$ & $\begin{array}{l}\text { Rhombohedral-protodolomite-R3c } \\
\text { Rhombohedral-ordered dolomite-R3 }\end{array}$ \\
\hline 4 & Huntite & $\begin{array}{l}\text { Gogolin Beds not calculated } \\
\text { Górażdże Beds not calculated } \\
\text { Dziewkowice Beds not calculated } \\
\text { Karchowice Beds } \\
\quad\left[\mathrm{Ca}_{0.48-0.40}, \mathrm{Mg}_{0.52-0.60} \mathrm{CO}_{3}\right]\end{array}$ & $a_{\mathrm{o}}=9.5027 \AA, c_{\mathrm{o}}=7.8212 \AA$ & Trapezohedral-R32 \\
\hline
\end{tabular}

webmineral.com/data/Dolomite.shtml; http://webmineral. com/data/Huntite.shtml; http://rruff.info/Huntite). The results of microprobe measurements show that the value of $\mathrm{Mg}$ in huntite phase is lower than the stoichiometric value for this carbonate phase. Primary huntite could undergo diagenetic processes (probably dehuntization). The effect of diagenetic changes was a reduction in the magnesium content in the huntite crystal (Stanienda 2013a, b). Because of this, the $\mathrm{Mg} / \mathrm{Ca}$ ratio for huntite was not calculated. The $\mathrm{Mg} / \mathrm{Ca}$ mole ratios of huntite range between 2.04 and 3.85, with an average of 2.77 (Yavuz et al. 2006).

\section{Discussion}

\section{Carbonate phases rich in magnesium in the rocks of the analyzed areas}

The results of the conducted analyses show that four carbonate phases were identified in all formations of Muschelkalk from the area of the Polish part of the
Germanic Basin: low-magnesium calcite (low-Mg calcite), high-Mg calcite (high-magnesium calcite/high-magnesiocalcite), dolomite (ordered dolomite) and huntite.

Low-magnesium calcite and high-Mg calcite are usually mixed in the rock mass of limestones poor in allochems or form micritic cement in limestones with bioclasts. Bigger low-magnesium sparry calcite grains often vary in size and shape. They form aggregates or fill veins. Xenomorphic, probably low-Mg, sparry calcite grains are often different in size and shape. They are products of diagenetic processes - aggradation and recrystallization of micritic grains of the primary carbonate material. Crystals of the calcite phase (probably low-magnesium calcite) often form palisade cement which surrounds bioclasts. Dolomite and huntite form usually euhedral, rhombohedral crystals. It is also impossible to distinguish these two phases during microscopic researches.

Results of X-ray diffraction, FTIR spectroscopy and microprobe measurements show that four carbonate phases with magnesium occur in all investigated limestones: lowmagnesium calcite, high-Mg calcite, dolomite and huntite. 
Low-magnesium calcite dominates among the carbonate phases in the analyzed samples. This carbonate phase was identified in diffractograms based on the diffraction lines typical for this phase. The diffraction line of the highest intensity was present for low-Mg calcite values of $d_{104}$ from 3.0329 to $3.037 \AA$. According to FTIR spectroscopy, low-magnesium calcite also predominates in the analyzed samples. It was identified in most of the samples, mainly on the basis of the infrared bands: $V_{4}=712 \mathrm{~cm}^{-1}$, $V_{2}=847 \mathrm{~cm}^{-1}$ and $V_{2}$-values from 872 to $874 \mathrm{~cm}^{-1}$, $V_{3}$-values from 1415 to $1422 \mathrm{~cm}^{-1}, V_{1}+V_{4}$-values from 1797 to $1799 \mathrm{~cm}^{-1}, V_{1}+V_{3}$-values from 2512 to $2513 \mathrm{~cm}^{-1}$, as well as some infrared bands of further infrared. The results of microprobe measurements show that in this carbonate phase, the content of magnesium present values below $1 \%$ of $\mathrm{Mg}$. In BSE images this carbonate phase is fair gray in color.

High-Mg calcite, which was impossible to determine during microscopic study, was indentified based on the results obtained with other methods: X-ray diffraction, FTIR spectroscopy and microprobe measurements. The results of X-ray diffraction show that high-magnesium calcite was identified in all samples based principally on the diffraction line of the highest intensity which present values of $d_{104}$ from $2.9497 \AA$ (sample SO14) to $2.9834 \AA$ (sample S2). In diffractogram of sample S2 (Dziewkowice limestone) apart from the diffraction line of the highest intensity, three other diffraction lines of lower intensities typical for high-Mg calcite phase were determined. In the diffractograms of seven samples (G1, G2, SA5, W1, S7, SO20), apart from the diffraction line of the highest intensity, also one more diffraction line of lower intensity typical for high-Mg calcite phase was determined. The results of FTIR spectroscopy confirmed the rule which tells that the values of absorption bands of high-magnesium calcite are usually higher than the ones of low-Mg calcite and lower than the values typical for dolomite. It can be stated that high-magnesium calcite is present in two of the investigated samples: G6 and SO20, except for the low-magnesium calcite and dolomite in sample G6. High-Mg calcite was identified based principally on the absorption band $V_{1}+V_{3}=2519 \mathrm{~cm}^{-1}$ in sample $\mathrm{G} 6$ and on the absorption bands of further infrared with the following values: 1087 and $2356 \mathrm{~cm}^{-1}$. The values of the absorption bands which allowed to identify high-Mg calcite are higher than the values typical for low-Mg calcite and lower than the ones typical for dolomite. The change of the absorption band value can indicate a variable content of magnesium in the crystals of highmagnesium calcite. An increase in the absorption band value indicates an increase in the amount of $\mathrm{Mg}$ ions in the high-Mg calcite crystal structure. The results of the microprobe measurements show that high-magnesium calcite occurs mainly in Dziewkowice limestones and Karchowice limestones. The content of magnesium in high-Mg calcite of Karchowice limestones is lower than the amount of this chemical element in Dziewkowice limestones.

Dolomite was determined in limestones of all of the Lower Muschelkalk Formation. The results of the microscopic study showed that dolomite phases (dolomite and huntite) form usually euhedral, rhombohedral crystals in rock mass. This carbonate phase was identified in most of the diffractograms. The exception is sample S2. In diffractogram of this sample, dolomite was not determined. Moreover, in the X-ray diffraction pattern of sample SA5, only one low-intensity diffraction line was identified, so the presence of dolomite in this sample is doubtful. But in sample SO14, the content of dolomite is nearly $50 \%$, so this limestone can be classified as dolomitic limestone. FTIR spectroscopy allowed to identify dolomite in six examined rocks (G6, SA5, W1, SO1, SO14 and S2). This carbonate phase was determined based principally on the absorption bands of further infrared which are typical for dolomite. The results of the microprobe measurements show that dolomite occurs mainly in Dziewkowice (Terebratule) limestones and Karchowice limestones. The content of $\mathrm{MgCO}_{3}$ in dolomite varies from $45.93 \%$ in rocks of Dziewkowice Beds to $46.72 \%$ in rocks of Karchowice Beds, so it is like the stoichiometric value for this carbonate phase.

Huntite occurs in small amounts in all examined samples. It was impossible to distinguish this carbonate phase from dolomite using petrographic microscope. In most of the diffractograms, huntite was identified based principally on the diffraction line of the highest intensity typical for that phase. Only in sample W1, apart from the diffraction line of the highest intensity, one more diffraction line of lower intensity typical for huntite phase was determined. FTIR spectroscopy allowed to identify huntite in four examined rocks. This carbonate phase, which has higher magnesium content than dolomite, was identified based on the infrared bands of the values: 469 and $800 \mathrm{~cm}^{-1}$ in sample $\mathrm{G} 1,1555 \mathrm{~cm}^{-1}$ in samples $\mathrm{G} 6$ and $\mathrm{S} 2$ and $1562 \mathrm{~cm}^{-1}$ in sample SO1. However, huntite was only identified using this analytical method on the basis of single bands and only in the limestones of the Gogolin and Dziewkowice Beds (Stanienda 2013a, b). Microprobe measurements allowed to identify huntite only in Karchowice limestones. The content of $\mathrm{MgCO}_{3}$ in huntite varies from 48.78 to $55.67 \%$, so it is lower than the stoichiometric value of this carbonate phase, which varies from 69.30 to $72.28 \%$ of $\mathrm{MgCO}_{3}$. The reduction of $\mathrm{Mg}$ in huntite may be an effect of diagenetic processes (probably dehuntization) (Stanienda 2013a, b). 


\section{Structures of the crystal cell and chemical formulas of carbonate phases rich in magnesium}

The results of the study presented in this article, the results of previously conducted research (Stanienda 2006, 2011, $2013 \mathrm{a}, \mathrm{b})$ and the literature data allow to determine the chemical formulas of the investigated carbonate phases with magnesium. Structures of the crystal cell and chemical formulas of carbonate phases rich in magnesium are presented in Table 7. Some data placed in this table come from previous studies (Althoff 1977; Kralj et al. 2004; Paquette and Reeder 1990; Stanienda 2013a; Titiloye et al. 1998; Tsipursky and Buseck 1993; Wenk et al. 1991). The chemical formula of low-magnesium calcite (low-Mg calcite) of the Lower Muschelkalk limestones is the same for the rocks of all beds (Stanienda 2013a). Big differences in magnesium content in low-magnesium calcite of limestones in the individual formations were not observed. Bigger differences in magnesium content occur in high-Mg calcite (high-magnesium calcite/high magnesio-calcite) (Table 7). The results of the calculations show a higher content of magnesium in high-Mg calcite of Dziewkowice Beds and Karchowice Beds and lower in Gogolin Beds and Górażdże Beds. It could be connected with the conditions of deposition and diagenetic processes. Diagenetic processes could generate and preserve this unstable carbonate phase in Muschelkalk rocks. Moreover, high-magnesium calcite characterized by different $\mathrm{Mg}$ content could come from shells and different parts of skeletons (Böttcher et al. 1997; Böttcher and Dietzel 2010; Boggs 2010; Nürnberg et al. 1996; Morse and Mackenzie 1990; Morse et al. 2006). However, the possibility of forming high-Mg calcite as a result of dolomite weathering cannot also be excluded.

The results of the studies show that in a single crystal cell of high-Mg calcite, which is built of 14 ions, 3 of them could be $\mathrm{Mg}$ ions and $11 \mathrm{Ca}$ ions (Stanienda 2013a). Zhang et al. (2010) established that it is possible to determine cell parameters- $a_{\mathrm{o}}(\AA)$ and $c_{\mathrm{o}}(\AA)$ of high-magnesium calcite on the basis of $\mathrm{MgCO}_{3}$ content. When the amount of $\mathrm{MgCO}_{3}$ is $22.7 \%$, the cell parameters of high-Mg calcite present general values as follows: $a_{\mathrm{o}}=4.91 \AA$, $c_{\mathrm{o}}=16.65 \AA$ , and for the amount of $\mathrm{MgCO}_{3} 36.71 \%$ the cell parameters present general values $a_{\mathrm{o}}=4.88 \AA$, $c_{\mathrm{o}}=16.45 \AA$ (Zhang et al. 2010). According to Paquette and Reeder (1990), the amount of $\mathrm{MgCO}_{3}$ in biogenic highmagnesium calcite fluctuates from 6.4 to $12.9 \mathrm{~mol} \%$. The results of their researches show that for the content $6.4 \mathrm{~mol} \%$ of $\mathrm{MgCO}_{3}$, the parameters of high-Mg calcite cell present the, following values:, $a_{\mathrm{o}}=4.9673(3) \AA$, $c_{\mathrm{o}}=16.9631(7) \AA, \quad V=362.48(4) \AA^{3}$ and the ratio $c_{\mathrm{o}} / a_{\mathrm{o}}=3.415$. If the content of $\mathrm{MgCO}_{3}$ is $12.9 \mathrm{~mol} \%$, the parameters of high-magnesium calcite crystal cell are $a_{\mathrm{o}}=4.9382(4) \AA, \quad c_{\mathrm{o}}=16.832(1) \AA, \quad V=355.48(7) \AA^{3}$ and the ratio $c_{\mathrm{o}} / a_{\mathrm{o}}=3.4085$ (Paquette and Reeder 1990). However, according to Johnson (2002), $a_{\mathrm{o}}$ and $c_{\mathrm{o}}$ cell parameters of high- $\mathrm{Mg}$ calcite for $13.6 \% \mathrm{Mg}$ substitution (47.6 mol\% of $\mathrm{MgCO}_{3}$ ) could be as follows: $a_{\mathrm{o}}=4.942 \AA$ and $c_{\mathrm{o}}=16.85 \AA$. It is probably connected with the distribution of magnesium ions and their position in a highmagnesium calcite crystal cell. Because of magnesium substitutions in the crystals of high-Mg calcite, the structure of the crystal cell is different in comparison with a lowmagnesium calcite crystal. It is connected with a difference in the size of ionic radius of $\mathrm{Ca}$ and ionic radius of $\mathrm{Mg}$ (Titiloye et al. 1998; Tsipursky and Buseck 1993). The cell parameters of high-Mg calcite of analyzed rocks were determined on the basis of Card Index ICDD from database PDF-4+ with number 04-008-806. Apart from high-magnesium calcite, other carbonate minerals rich in magnesium also exist, such as protodolomite, ordered dolomite, huntite and magnesite (Table 7) (Böttcher et al. 1997). The symmetry of high-magnesium calcite crystal is rhombohedral (Althoff 1977; Kralj et al. 2004; Paquette and Reeder 1990; Wenk et al. 1991), similar to the typical one for protodolomite. Dolomite of Muschelkalk limestones of the Polish part of the Germanic Basin have a stoichiometric value of $\mathrm{MgCO}_{3}$ for dolomite, so it can be treated as ordered dolomite. The results of the studies showed that in the Triassic carbonate rocks of the shelly Muschelkalk limestone of the Polish part of the Germanic Basin (Opole Silesia), a mineral which could be treated as huntite was identified. However, this carbonate phase belongs to a different space group than other carbonates rich in magnesium. Its structure is characterized by trapezohedral space group not rhombohedral (Table 7) (Faust 1953). The results of the study show that huntite of lower Muschelkalk limestones of the Polish part of the Germanic Basin presents lower value of $\mathrm{MgCO}_{3}$ than typical for this carbonate phase, which varies from 69.30 to $72.28 \%$ of $\mathrm{MgCO}_{3}$. The reduction of $\mathrm{Mg}$ in this mineral can be an effect of the diagenetic processes.

\section{Environments of carbonate phases with magnesium formation}

The results of the studies show that low-magnesium calcite and high-Mg calcite (the carbonate phase with higher content of $\mathrm{Mg}$ than low-magnesium calcite, but lower than dolomite) was formed in the epicontinental Germanic Basin during direct crystallization from seawater, at the same time as aragonite. These minerals were formed in a shallow sea, in an environment of warm, salty seawater rich in magnesium ions. Some amounts of magnesium could come from sea organisms, shells and various parts of skeletons; in case of the investigated limestones it could be Crinoids, which like the entire phylum Echinodermata 
contains the original high-Mg calcite. Dolomite concentrations do not form in an open sea. Because of their sedimentologic feature, dolomites have been deposited in mainly continental shallow-water environments, at considerably shallower depth and cooler temperatures $\left(20-30{ }^{\circ} \mathrm{C}\right)$ (Mackenzie and Andersson 2013; Whitaker and Xiao 2010). It could also be an effect of a dolomitization process which was going on during early burial (Whitaker and Xiao 2010). Dolomite of Lower Muschelkalk rocks of the Polish part of the Germanic Basin was probably formed in a shallow-water environment, in a mixing zone of the waters from the phreatic zone and salty seawaters in an early period of constructive diagenesis, an effect of the dolomitization processes. Such conditions thus brought about the formation of carbonate cement enriched in magnesium. Most probably, due to the presence of waters of this zone, which had an elevated content of dissolved mineral components, also the fixation process of an unstable carbonate phase of high-magnesium calcite which was originally formed in the environment of the seabed took place there (Stanienda 2013a). Huntite is a specific carbonate phase enriched in magnesium to a higher extent than high-Mg calcite or dolomite. This carbonate phase can occur in rocks of various types such as magmatic, sedimentary and metamorphous rocks, in sediments of various geological periods (Cole and Lancucki 1975). Huntite is usually formed as an effect of hydrothermal processes, weathering of dolomite or as a result of the transformation of magnesium calcite under high temperature conditions. In sedimentary rocks, it appears in the sediments of the vadose zone (Deelman 2011; Stanienda 2013a, b). When analyzing the possibilities involving the formation of huntite, we can assume that this mineral was formed in the areas of the Germanic Basin in which diagenetic processes were taking place with the contribution of waters from the vadose zone.

\section{Application of limestone with magnesium in power plants}

Analyzing the possibility of application of limestones, which includes mineral phases with magnesium, it can be said that these rocks can be used as a sorbent in desulfurization processes of flue gases in power plants. The effectiveness of the desulfurization process is higher with the application of sorbent limestone with higher content of carbonate phases rich in magnesium, because decarbonization of mineral phases rich in magnesium occurs at lower temperature than decarbonization of the "poor" calcite (low-Mg calcite). It is connected with the difference in size of calcium and magnesium ions and the strength of ionic bonds. Substitution of magnesium in the carbonate phases causes a decrease of ionic bond strength, so the crystal structure of the carbonate phases with magnesium substitution are not as stable as the "poor" calcite phase. Because of it, the crystal structure of the carbonate phase with magnesium substitution is easier to be destroyed than the calcite which includes only $\mathrm{Ca}$ cations. Therefore, lower temperatures of decarbonization of the phases rich in magnesium causes an earlier oxide secretion from carbonate minerals. For that reason, the binding of sulfur oxides by calcium and magnesium oxides and REA gypsum formation occurs earlier. Because of it, the desulfurization process is more effective. Therefore, limestones with higher content of carbonate phases rich in magnesium are better sorbents than the "poor" limestone built only of low-Mg calcite. The process of desulfurization is very important because it allows to reduce the emission into the atmosphere of sulfur oxides, which are emitted during coal combustion in power plants.

\section{Conclusions}

One of the most important results from the investigation of carbonate phases which build Triassic limestones of the Polish part of the Germanic Basin is the identification of differences between the content of magnesium in these phases. The results indicate the presence of four carbonate phases with magnesium in Triassic limestones of the Polish part of the Germanic Basin, which are: low-Mg calcite, high-magnesium calcite, dolomite and huntite. These carbonate phases were identified in rocks of all formations of the Polish lower Muschelkalk profile, including from the bottom Gogolin Beds, next Górażdże Beds, Dziewkowice (Terebratula) Beds and Karchowice Beds (the upper part of the analyzed profile). It was also very important to form a theory about the environment and conditions of the formation of carbonates. Moreover, it is necessary to have knowledge about the possibility of application of Muschelkalk limestone rich in magnesium in different branches of industry, especially in desulfurization of flue gases in power plants.

Two generations of low-Mg calcite were observed in limestones. The first type is micritic low-magnesium calcite which builds, together with high-Mg calcite, the rock mass of limestones poor in allochems or cement, which joins bioclasts or palisade cements that surround bioclasts. The first generation of low-Mg calcite is primary in origin. The second generation of low-magnesium calcite forms sparry crystals different in size and shape. It was formed during diagenetic processes-aggradation, recrystallization and transformation of micritic grains of primary carbonate material. The chemical formula of low-magnesium calcite of the Lower Muschelkalk limestones can be demonstrated as follows: $\left(\mathrm{Ca}_{1.00-0.98}, \mathrm{Mg}_{0-0.02}\right) \mathrm{CO}_{3}$. High-magnesium 
calcite forms micritic grains. It is mixed with low-Mg calcite and builds together with low-Mg calcite the rock mass of limestones or micritic cement which joins bioclasts. The chemical formula of high-Mg calcite of Gogolin limestones is $\mathrm{Ca}_{0.90} \mathrm{Mg}_{0.10} \mathrm{CO}_{3}$, in high-Mg calcite of Górażdże limestones it presents the form of $\left(\mathrm{Ca}_{0.92-0.90}\right.$,$\left.\mathrm{Mg}_{0.08-0.10}\right) \mathrm{CO}_{3}$, the one of Dziewkowice (Terebratula) limestones is $\left(\mathrm{Ca}_{0.77-0.60}, \mathrm{Mg}_{0.23-0.40}\right) \mathrm{CO}_{3}$, and that of Karchowice limestones is $\left(\mathrm{Ca}_{0.73-0.68}, \mathrm{Mg}_{0.27-0.32}\right) \mathrm{CO}_{3}$. Dolomite observed in analyzed limestones forms usually euhedral, rhombohedral crystals in the rock mass. The results of the study show that it has a stoichiometric value of $\mathrm{MgCO}_{3}$ typical for dolomite, so it can be treated as ordered dolomite. The content of $\mathrm{Ca}$ and $\mathrm{Mg}$ in dolomite of Dziewkowice Beds rocks is $\left[\mathrm{Ca}_{0.53}, \mathrm{Mg}_{0.47} \mathrm{CO}_{3}\right]$ and of Karchowice Beds rocks is $\left[\mathrm{Ca}_{0.53-0.51}, \mathrm{Mg}_{0.47-0.49} \mathrm{CO}_{3}\right]$. In the analyzed limestones, also huntite (a carbonate phase characterized by a higher content of magnesium than dolomite) was identified. The results of the study show that huntite of lower Muschelkalk limestones of the Polish part of the Germanic Basin has a lower value of $\mathrm{MgCO}_{3}$ than typical for this carbonate phase, so it is not stoichiometric huntite. The content of $\mathrm{Ca}$ and $\mathrm{Mg}$ in huntite is $\left[\mathrm{Ca}_{0.48-0.40}, \mathrm{Mg}_{0.52-0.60} \mathrm{CO}_{3}\right]$. The reduction of $\mathrm{Mg}$ in this mineral is probably an effect of diagenetic processes (dehuntization).

According to the results, micritic carbonate phases with magnesium of the Polish part of the Germanic Basin were formed in shallow sea, in an environment of warm, salty seawater rich in magnesium ions. Micritic, low-Mg calcite and high-Mg calcite are the products of direct crystallization from seawater. This process occurred during sediment compaction and an early stage of diagenesis (eogenetic stage). Sparry crystals of low-Mg calcite are the secondgeneration grains. They are the effects of diagenetic processes-aggradation, recrystallization and transformation of the primary micritic carbonate material, so they are very often different in size and shape. Dolomite was probably formed in the mixing zone of the waters from the phreatic zone and salty seawaters in the early period of constructive diagenesis, an effect of the dolomitization processes. Huntite identified in the limestones of the Polish part of the Germanic Basin is probably a product of diagenetic processes which were taking place with a contribution of waters from the vadose zone. Diagenesis caused also a reduction of $\mathrm{Mg}$ content in huntite crystals.

Limestones containing mineral phases rich in magnesium can be used as sorbents in desulfurization of flue gases in power plants. Limestones with magnesium are better sorbents than the "poor" limestone built only of low$\mathrm{Mg}$ calcite. The effectiveness of the desulfurization process is higher with an application of a sorbent limestone which includes carbonate phases rich in magnesium, because decarbonization of these mineral phases occurs in a lower temperature than decarbonization of the "poor" calcite (low-Mg calcite). It is connected with easier oxide secretion from the carbonate minerals, which allows for their earlier binding to sulfur oxides and REA gypsum formation. It is possible because of differences in size of calcium and magnesium ions and the strength of ionic bonds, which makes the destruction of carbonate phase crystals rich in magnesium easier, so the decarbonization of carbonate minerals rich in magnesium occurs at lower temperatures. It makes the process of desulfurization of flue gases in power plants more effective, especially in the case of an application of a conventional dry method or method uses a fluidized bed.

The results of the research are very important because they delivered new data connected with differentiation of mineral phases which build the Triassic carbonate rocks of the Polish part of the Germanic Basin. The investigated samples are representative rock samples for Lower Muschelkalk formations of the Polish part of the Germanic Basin. It is significant for a comparison of these rocks with the Muschelkalk rocks in other areas. The sediments of the Germanic Basin occur also in other countries of Europe, so the data can be compared with information connected with mineral composition of Triassic carbonate rocks situated in other places in Europe. It could be also applied to an analysis of Triassic carbonate rocks in other places of the world, especially for a comparison of the mineral composition of Triassic limestones and environments of carbonate phase formation.

Open Access This article is distributed under the terms of the Creative Commons Attribution 4.0 International License (http://creative commons.org/licenses/by/4.0/), which permits unrestricted use, distribution, and reproduction in any medium, provided you give appropriate credit to the original author(s) and the source, provide a link to the Creative Commons license, and indicate if changes were made.

\section{References}

Ahn DJ, Berman A, Charych D (1996) Probing the dynamics of template-directed calcite crystallization with in situ FTIR. J Phys Chem 100:12455-12461

Althoff PL (1977) Structural refinements of dolomite and a magnesian calcite and implications for dolomite formation in the marine environment. Am Mineral 62:772-783

Bayliss P, Erd DC, Mrose ME, Sabina AP, Smith DK (1986) Mineral powder diffraction file. Search manual. Chemical name. Hanawalt. Fink. Mineral name. International Centre for Diffraction Data, USA

Bayliss P, Erd DC, Mrose ME, Sabina AP, Smith DK (1986b) Mineral powder diffraction file. Data book. International Centre for Diffraction Data, USA

Bertram MA, Mackenzie FT, Bishop FC, Bischoff WD (1991) Influence of temperature on the stability of magnesian calcite. Am Mineral 76:1889-1896 
Boggs S Jr (2010) Petrology of sedimentary rocks, 2nd edn. Cambridge University Press, Cambridge, pp 313-457

Böttcher ME, Dietzel M (2010) Metal-ion partitioning during lowtemperature precipitation and dissolution of anhydrous carbonates and sulphates. In: EMU notes in mineralogy, vol 10, pp 139-187

Böttcher ME, Gehlken PL, Steele FD (1997) Characterization of inorganic and biogenic magnesian calcites by Fourier Transform infrared spectroscopy. Solid State Ion 101-103:1379-1385

Cole WF, Lancucki CJ (1975) Huntite from Deer Park, Victoria, Australia. Am Mineral 60:1130-1131

Deelman JC (2011) Magnesite and huntite. In: Low-temperature formation of dolomite and magnesite. http://www.jcdeelman. demon.nl/dolomite/files/13_Chapter6.pdf

Deer WA, Howie RA, Zussman J (1962) Rock-forming minerals. Vol 5 Non-silicates. Longmans, Green and Co Ltd, London

Dollase WA, Reeder RJ (1986) Crystal structure refinement of huntite, $\mathrm{CaMg}_{3}\left[\mathrm{CO}_{3}\right]_{4}$, with X-ray powder data. Am Mineral 71:163-166

Fairbridge RW (1957) Soc Econ Paleontol Mineral Spec Pub 5:164-170

Faust GT (1953) Huntite, $\mathrm{Mg}_{3} \mathrm{Ca}\left(\mathrm{CO}_{3}\right)_{4}$, a new mineral. Am Mineral 38:4-23

Feist-Burkhard TS, Götz AE, Szulc J, Borkhataria R, Geluk M, Haas J, Hornung J, Jordan P, Kempf O, Michalik J, Nawrocki J, Reinhardt L, Rickem W, Röhling HG, Rüffer T, Török Á, Zühlke R (2008) Triassic. In: McCann T (ed) The geology of Central Europe Volume 2: Mesozoic and Cenozoic. The Geological Society, London

Flügel E (2004) Microfacies in carbonate rocks. Analysis, interpretation and application. Springer, Berlin

Goffredo S, Caroselli E, Mezzo F, Laiolo L, Vergni P, Pasquini L, Levy O, Zaccanti F, Tribollet A, Dubinsky Z, Falini G (2012) The puzzling presence of calcite in skeletons of modern solitary corals from the Mediterranean Sea. Geochim Cosmochim Acta 85:187-199

Ji J, Ge Y, Balsam W, Damuth JE, Chen J (2009) Rapid identification of dolomite using a Fourier Transform Infrared Spectrophotometer (FTIR): a fast method for identifying Heinrich events in IODP Site U1308. Mar Geol 258:60-68

Johnson N (2002) Kratos Analytical, A Shimadzu Group Company. http://www.kratos.com/XRD/Apps/geol.html

Kralj D, Kontrec J, Brecěvć L, Falini G, Nöthig-Laslo V (2004) Effect of inorganic anions on the morphology and structure of magnesium calcite - chemistry-A. Eur J 10:1647-1656

Mackenzie FT, Andersson AJ (2013) The Marine carbon system and ocean acidification during Phanerozoic time. Geochem Perspect 2(1): $1-3$

Morse JW, Mackenzie FT (1990) Geochemistry of sedimentary carbonates, vol 33. Elsevier, New York, p 707

Morse JW, Andersson AJ, Mackenzie FT (2006) Initial responses of carbonate-rich shelf sediments to rising atmospheric $\mathrm{pCO}_{2}$ and "ocean acidification": role of high $\mathrm{Mg}$-calcites. Geochim Cosmochim Acta 70:5814-5830

Nash MC, Troitzsch U, Opdyke BN, Trafford JM, Russell BD, Kline DI (2011) First discovery of dolomite and magnesite in living coralline algae and its geobiological implications. Biogeosciences 8:3331-33340

Nürnberg D, Bijma J, Hemleben C (1996) Assessing the reability of magnesium in foraminiferal calcite as a proxy for water mass temperatures. Geochimica et Cosmochimica Acta 60(5):803-814
Paquette J, Reeder RJ (1990) Single-crystal X-ray structure refinements of two biogenic magnesian calcite crystals. Am Mineral 75:1151-1158

Pawloski GA (1985) Quantitative determination of mineral content of geological samples by X-ray diffraction. Am Mineral 70:663-667

Pokrovsky OS, Mielczarski JA, Barrea O, Schott J (2000) Surface spaciation models of calcite and dolomite aqueous solution interfaces and their spectroscopic evaluation. Langmuir 16:2677-2688

Radha AV, Fernandez-Martinez A, Hu Y, Jun YS, Waychunas GA, Navrotsky A (2012) Energetic and structural studies of amor-

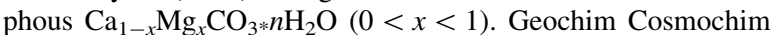
Acta 90:83-95

Ramseyer K, Miano TM, D’Orazio V, Wildberger A, Wagner T, Geister J (1997) Nature and origin of organic matter in carbonates from speleothems, marine cements and coral skeletons. Org Geochem 26(5/6):361-378

Stanienda K (2006) Carbonates in the Triassic rocks from the area of Tarnów Opolski. In: Mineral resources management, vol 22, special issue 3. Kraków, pp 243-251

Stanienda K (2011) Effects of dolomitization processes in the Triassic limestone of Tarnów Opolski Deposit. Silesian University of Technology Press, Gliwice

Stanienda K, Nowak J, Kukiełka T (2012) Mineral phases of carbonate Triassic rocks of the Chorzów area. In: Mineral Resources Management, vol 28, issue 3. Kraków, pp 71-91

Stanienda K (2013a) Diagenesis of the Triassic limestone from the Opole Silesia in the aspect of magnesian calcite presence. Silesian University of Technology Press, Gliwice

Stanienda K (2013b) Huntite in the Triassic limestones of Opole Silesia. In: Mineral resources management, vol 29, issue 3. Kraków, pp 79-98

Szulc J (1990) International workshop-field seminar the Muschelkalksedimentary environments, facies and diagenesis-excursion guidebook and abstracts. Kraków-Opole, pp 1-32

Szulc J (2000) Middle Triassic evolution of the Northern Peri-Tethys area is influenced by early opening of the Tethys Ocean. Ann Soc Geol Pol 70:1-48

Titiloye JO, De Leeuw NH, Parker SC (1998) Atomistic simulation of the differences between calcite and dolomite surfaces. Geochim Cosmochim Acta 62(15):2637-2641

Tsipursky SJ, Buseck PR (1993) Structure of magnesian calcite from sea urchins. Am Mineral 78:775-781

Tucker ME, Wright VP (1990) Carbonate sedimentology. Blackwell Scientific Publications, Oxford, pp 366-372

Wenk HR, Meisheng H, Lindsey T, Morris JW Jr (1991) Super structures in ankerite and calcite. Phys Chem Miner 17:527-539

Whitaker FF, Xiao Y (2010) Reactive transport modeling of early burial dolomitization of carbonate platforms by geothermal convection. AAPG Bull 94(6):889-917

Yavuz F, Kirikoğlu MS, Özden G (2006) The occurrence and geochemistry of huntite from Neogene lacustrine sediments of the Yalvaç-Yarıkkaya Basin, Isparta, Turkey. Neues Jahrbuch Fur Mineralogie- Abhandlungen 182/2:201-212. Stuttgart, April 2006, published online 2006

Zhang F, Xu H, Konishi H, Roden EE (2010) A relationship between $d_{104}$ value and composition in the calcite-disordered dolomite solid-solution series. Am Mineral 95:1650-1656 